\title{
Petrography, geochemistry and Sm-Nd isotopes of the granites from eastern of the Tapajós Domain, Pará state
}

\author{
Petrografia, geoquímica e isótopos Sm-Nd de granitos \\ do leste do Domínio Tapajós, estado do Pará
}

\author{
Flávio Robson Dias Semblano ${ }^{1 *}$, Moacir José Buenano Macambira ${ }^{2}$, \\ Marcelo Lacerda Vasquez ${ }^{3}$
}

\begin{abstract}
The Tapajós Domain, located in the southern portion of the Amazonian Craton, is a tectonic domain of the Tapajós-Parima Province, a Paleoproterozoic orogenic belt adjacent to a reworked Archean crust, the Central Amazonian Province. This domain has been interpreted as the product of an assemblage of successive magmatic arcs followed by post-orogenic A-type magmatism formed ca. $1880 \mathrm{Ma}$-old granites of the Maloquinha Intrusive Suite. The study presented here was carried out in four granitic bodies of this suite (Igarapé Tabuleiro, Dalpaiz, Mamoal and Serra Alta) from the eastern part of the Tapajós Domain, as well as an I-type granite (Igarapé Salustiano) related to the Parauari Intrusive Suite. The A-type granites are syenogranites and monzogranites, and alkali feldspar granites and quartz syenites occur subordinately. These rocks are ferroan, alkalic-calcic to alkalic and dominantly peraluminous, with negative anomalies of $\mathrm{Ba}, \mathrm{Sr}, \mathrm{P}$ and $\mathrm{Ti}$ and high rare earth elements (REE) contents with pronounced negative Eu anomaly. This set of features is typical of A-type granites. The Igarapé Salustiano granite encompasses monzogranites and quartz monzonites, which are magnesian, calcic to calc-alkalic, high-K and mainly metaluminous, with high $\mathrm{Ba}$ and $\mathrm{Sr}$ contents and depleted pattern in high field strength elements (HFSE) and heavy rare earth elements (HREE), characteristic of I-type granites. The source of magma of these A-type granites is similar to post-collisional granites, while the I-type granite keeps syn-collisional signature. Most of the studied granites have $\varepsilon_{\mathrm{Nd}}$ (-3.85 to -0.76$)$ and $\mathrm{Nd}_{\mathrm{DM}}$ model ages (2.22 to $2.46 \mathrm{Ga}$ ) compatible with the Paleoproterozoic crust of the Tapajós Domain. We conclude that the Archean crust source $\left(\varepsilon_{\mathrm{Nd}}\right.$ of -5.01 and $\mathrm{Nd} \mathrm{T}_{\mathrm{DM}}$ of $2.6 \mathrm{Ga}$ ) was local for these A-type granites.
\end{abstract}

KEYWORDS: Maloquinha Intrusive Suite; Parauari Intrusive Suite; Granites; Orosirian; Amazonian Craton.
RESUMO: O Dominio Tapajós, localizado na porção sul do Cráton Amazônico, é um dominio tectônico da Provincia Tapajós-Parima, um cinturão orogênico Paleoproterozoico, adjacente a uma crosta arqueana retrabalhada, a Provincia Amazônia Central. Esse dominio foi interpretado como resultado da acreção de sucessivos arcos magmáticos, seguidos por um magmatismo pós-orogênico do tipo $A$, representado por granitos de ca. 1880 Ma da Suite Intrusiva Maloquinha. Este estudo foi realizado em quatro granitos dessa suite (Igarapé Tabuleiro, Dalpaiz, Mamoal e Serra Alta) da porção leste do Dominio Tapajós, assim como um granito tipo I (Igarapé Salustiano), relacionado à Suite Intrusiva Parauari. Os granitos tipo A são sienogranitos e monzogranitos, e subordinadamente feldspato alcalino granitos e quartzo sienitos. Essas rochas são ferrosas, alcalicálcica a alcalinas e dominantemente peraluminosas, com anomalias negativas de Ba, Sr, P e Ti, e alto conteúdo de elementos terras raras (ETR) com pronunciada anomalia negativa de Eu. Esse conjunto de características é típico de granitos tipo A. O Granito Igarapé Salustiano apresenta monzogranitos e quartzo monzonitos magnesianos, cálcicos a calcioalcalinos, alto $\mathrm{Ke}$ dominantemente metaluminosos, com alto conteúdo de Ba e Sr, e empobrecidos em high field strength elements (HFSE) e ETR pesados, caracteristicos de granitos do tipo I. A fonte do magma dos granitos tipo A é similar a de granitos pós-colisionais, enquanto os granitos tipo I mantêm assinatura sincolisional. A maioria dos granitos estudados tem $\varepsilon_{N d}(-3,85$ a $-0,76)$ e idades modelo $N d T_{D M}(2,22$ a 2,46 Ga) compativeis com a crosta paleoproterozoica do Domínio Tapajós. Conclui-se que fonte crustal arqueana $\left(\varepsilon_{N d}\right.$ de -5,01 e $N d T_{D M}$ de 2,6 Ga) é local para os granitos tipo $A$.

PALAVRAS-CHAVE: Suite Intrusiva Maloquinha; Suite Intrusiva Parauari; Granitos; Orosiriano; Cráton Amazônico.

\footnotetext{
${ }^{1}$ Programa de Pós-graduação em Geologia e Geoquímica, Instituto de Geociências, Universidade Federal do Pará - UFPA, Belém (PA), Brasil. E-mail: frdsemblano@yahoo.com.br

${ }^{2}$ Laboratório de Geologia Isotópica, Universidade Federal do Pará - UFPA, Belém (PA), Brasil. E-mail: moamac@ufpa.br

3Serviço Geológico do Brasil, Companhia de Pesquisa de Recursos Minerais - CPRM, Superintendência Regional de Belém - SUREG-Belém, Belém (PA), Brasil. E-mail:marcelo.vasquez@cprm.gov.br

*Corresponding author

Manuscript ID: 20160059. Received in: 05/01/2016. Approved in: 10/26/2016
} 


\section{INTRODUCTION}

As well as other terrains of the Amazonian Craton, the Tapajós Domain hosts meaningful Paleoproterozoic granitoids related to formation of the Tapajós-Parima province (Fig. 1) (Santos et al. 2000; 2004). In this context the Maloquinha Intrusive Suite (MIS) is included. It is a significant suite that was initially proposed by Santos et al. (1975) as Maloquinha granites to group several subcircular granitic plutons, widely distributed in the Tapajós Domain. In subsequent work, several similar plutons have been mapped, and Andrade et al. (1978) proposed the name Maloquinha Intrusive Suite for these granitic plutons. These granites are characterized by an alkaline affinity (A-type), typical of intracontinental or post-collisional environments. MIS appears to postdate the Tropas Orogeny (Santos et al. 2004), which originated the Parauari Intrusive Suite (PIS) rocks.

However, many granitic plutons of alkaline affiliation that outcrop in the Tapajós Domain were arbitrarily grouped as MIS, often for a lack of more detailed studies. The Pepita granite, for example, which outcrops on Tapajós River as a batholith of ellipsoidal shape, was included in the MIS. Based on the occurrence of sodic amphibole and pyroxene, Brito (2000) proposed to distinguish it from MIS granites, calling it the Pepita granite. Subsequently, Santos et al. (2004) presented the age of $1872 \pm 4 \mathrm{Ma}$ (U-Pb sensitive high-resolution ion microprobe — SHRIMP — in zircon), for the emplacement of the Pepita granite, confirming what was suggested by Brito (2000). Another example is the Porquinho granite, a batholith located in the interfluve of Branco and Aruri rivers (southwestern of Pará state), which was also correlated with MIS (Pessoa et al. 1977; Almeida et al. 1977). However, the determination of a subalcaline to alkaline signature, combined with $1786 \pm 14 \mathrm{Ma}$ crystallization age (Santos et al. 2004), obtained by U-Pb SHRIMP in zircon, led the authors to correlate it with Teles Pires Intrusive Suite magmatism, from Juruena Domain, in Mato Grosso state.

Despite development of additional geological knowledge in the last few years (e.g. Lamarão et al. 2002; 2005; Vasquez et al. 2002; Santos et al. 2001; 2004), the Tapajós Domain still lacks geological, geochemical and isotopic studies of greater detail and accuracy. Studies of this nature have advanced more slowly in the Amazonian Craton than in the rest of the country. This results from the difficulties imposed by the region, mainly logistic ones, due to the presence of dense forest and lack of access that require huge efforts in carrying out geological surveys. This paper intends to determine the geochemical signature and investigate the sources of magmas of the felsic igneous rocks of the eastern portion of the Tapajós Domain, in the SB.21-ZA-II (São Domingos) and SB.21-Z-A-III (Jardim do Ouro)
1:100,000 sheets, based upon petrographic, isotopic ( $\mathrm{Sm}-\mathrm{Nd}$ whole rock) and lithochemical studies.

\section{REGIONAL GEOLOGICAL CONTEXT}

Located in the northern portion of South America, the Amazonian Craton (Almeida et al. 1981) is one of the main tectonic units of the South American Platform. Several models have been proposed for a tectonic subdivision of the Amazonian Craton (Cordani et al. 1979; Teixeira et al. 1989; Tassinari 1996). Among the most discussed proposals, the ones of Santos et al. (2000) and Tassinari and Macambira (1999; 2004) stand out. The main disagreements between the two of them concern the limits and time intervals of tectonic provinces, though both agree that the evolution of the craton is the result of successive episodes of crustal accretion during the Paleo and Mesoproterozoic, around an ancient core stabilized in Neoarchean.

The region of interest here is in a critical transition between Tapajós and Iriri-Xingu domains, respectively southern portions of Tapajós-Parima and Central Amazonian provinces (Fig. 1). Yet, the boundary between these domains described by Santos et al. (2000) and Tassinari and Macambira (1999; 2004) require reevaluation in light of the work presented here, as well as other recent efforts in this region (Vasquez et al. 2008a; Semblano et al. 2016). Thus, this work adopted the tectonic subdivision model presented by Vasquez et al. (2008a) (Fig. 1), which was initiated by Santos et al. (2000) (reviewed in Santos 2003) with the warning that the Tapajós/ Iriri-Xingu limit was eastward, in the Iriri-Xingu Domain. According to this author, the Amazonian Craton is split in seven tectonic or geochronological provinces: Carajás (3000$2500 \mathrm{Ma}$ ), Transamazonas (2260-1990 Ma), Tapajós-Parima (2030-1860 Ma), Central Amazonian (1900-1860 Ma), Rondônia-Juruena (1850-1540 Ma), Rio Negro (1820$1520 \mathrm{Ma}$ ) and Sunsás (1450-1000 Ma).

The Tapajós Domain is part of a paleoproterozoic orogenic belt called Tapajós-Parima (Santos et al. 2001; 2004). This terrain was firstly defined by Tassinari (1996), and it was pulled apart from the archean core of the Amazonian Craton (Central Amazonian Province) as a 1.95-1.80 Ga paleoproterozoic orogenic belt (called Ventuari-Tapajós Province) with NW-SE orientation, extending from southwestern of the state of Pará to the southern of Venezuela. The TapajósParima orogenic belt is one of the main provinces of the craton. It represents new crust added to the core of the craton during Paleoproterozoic (2.10 to $1.87 \mathrm{Ga}$, Santos et al. 2000) and is surrounded westward by younger paleoproterozoic provinces, which were added to the craton between 1.85 and 1.70 Ga (Rio Negro and Rondônia-Juruena provinces). 
According to Santos et al. $(2001 ; 2004)$, the formation of the Tapajós-Parima Province is marked by the development of two distinct orogenies that incorporated four magmatic arcs followed by post-orogenic alkaline magmatism.
The first magmatic arc (Cuiú-Cuiú complex) was generated between 2.03 and $2.00 \mathrm{Ga}$ and was likely an island arc whose remnants are mainly metatonalites and metabasalts. The second arc (calc-alkaline), called the Creporizão arc,

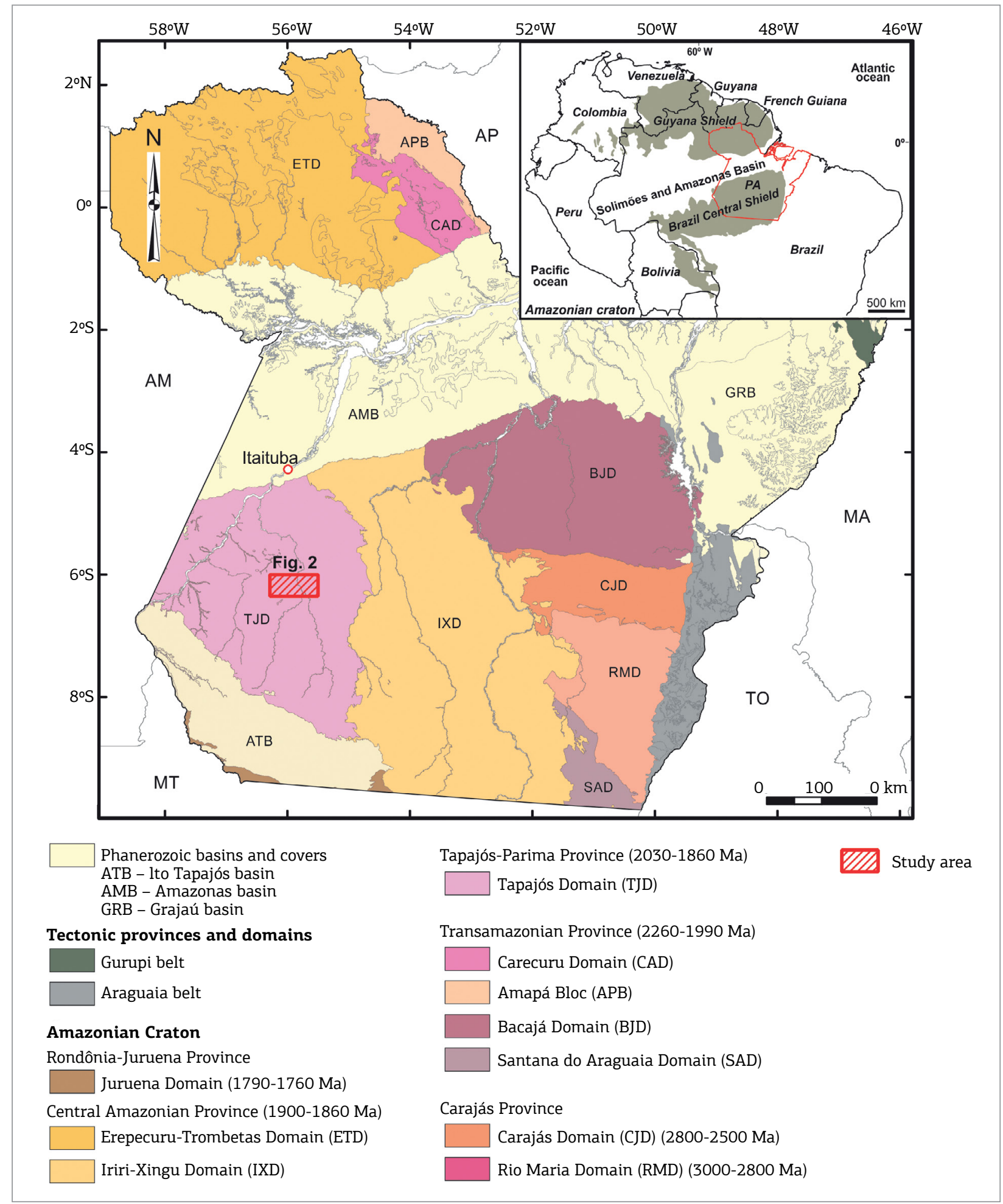

Figure 1. Provinces and tectonic domains of state of Pará (Vasquez et al. 2008a, modified from Santos 2003). 
was generated between 1980 and $1950 \mathrm{Ma}$, and exhibits evidence for previous incorporation of continental crust, composed of monzogranites and andesites. These first two arcs form the Mundurucus orogeny. After a hiatus of about 50 million years, a new orogen developed initially by the formation of and the collision to another primitive islands arc. This arc was added to the continent between 1900 and $1890 \mathrm{Ma}$ (Tropas arc) and is composed of tonalite, basalts, and andesites. This arc collision was followed by another collision with a continental arc called Parauari, characterized by monzogranites and felsic volcanic rocks (1883-1879 $\mathrm{Ma}$ ). The post-orogenic magmatism (Maloquinha Intrusive Suite and Iriri Group volcanic rocks) took place around 1870 million years ago, shortly after the development of Parauari arc. Alternatively, there was a collision of only one arc (Cuiú-Cuiú/Anauá arc), followed by post-collisional and extensional magmatic events with associated underplating (Vasquez et al. 2002).

The MIS comprises alkali granites generated in post-collisional environments and are spatially associated with volcanic rocks of the Iriri Group. This suite consists of alkali feldspar granite, syenogranite and leucocratic monzogranite plutons with a pertitic orthoclase predominance and rare microcline. They outcrop as stocks and elliptical to circular batholiths along NW-SE regional lineament. Chemically, these rocks are metaluminous to peraluminous and subalkaline to alkaline with high $\mathrm{SiO}_{2}$ content (70.3-76.6\%, Lamarão et al. 2002), enriched in alkalis, high $\mathrm{FeO}_{\mathrm{t}} / \mathrm{MgO}$ and $\mathrm{K}_{2} \mathrm{O} / \mathrm{Na}_{2} \mathrm{O}$ ratios and low in $\mathrm{CaO}, \mathrm{Al}_{2} \mathrm{O}_{3}, \mathrm{Ba}$, Sr and Ti contents. Their petrographic, chemical and rare earth elements (REE) pattern are similar to those described for A-type granites by Eby (1992). Additionally, it seems as the calc-alkaline volcanic rocks of the Iriri Group were not emplaced during the Maloquinha alkaline magmatic event, though, which led Juliani et al. (2005) to consider that the volcanic rocks of Iriri Group are part of the late- to post-collisional set of Parauari calc-alkaline magmatic event. These alkaline volcanic rocks can be correlated with the Moraes Almeida (Lamarão et al. 2002) and Santa Rosa formations (Juliani and Fernandes 2010). The MIS granitoids correspond to a post-orogenic generation of the Parauari Intrusive Suite (Santos et al. 2004). It comprises unfoliated and isotropic plutons split in two petrographic facies: granodioritic, predominantly composed of leucocratic monzogranites and granodiorites; and granitic, composed of monzogranites, syenogranites and subordinate porphyritic units (Vasquez et al. 2008b), both of which intrude the Cuiú-Cuiú and Creporizão granitoids.

Like the MIS in the Tapajós Domain, Paleoproterozoic (ca. $1.88 \mathrm{Ga}$ ) A-type anorogenic magmatism is recorded in several other parts of the Amazonian Craton. In Rio Maria
Domain (Carajás Province), there is also a meaningful record of this magmatism. The oxidized A-type granites of Rio Maria Domain were grouped with the Jamon Suite, and moderately reduced A-type granites were clustered in Serra dos Carajás Suite (Dall'Agnol et al. 1999a). The Jamon Suite is composed of Jamon, Musa, Redenção and Banach granitic plutons. Serra dos Carajás Suite granites are represented by Serra dos Carajás, Cigano, Seringa and São João plutons, showing petrographic and geochemical features similar to the Jamon Suite, contrasting with it chiefly by the Serra dos Carajás's slightly reduced nature. In the Carajás Province, the Velho Guilherme, Antônio Vicente, Mocambo and Rio Xingu massif granites belong to the Velho Guilherme Intrusive Suite. In Iriri-Xingu Domain (Central Amazonian Province) there is also an important record of plutonic and volcanic rocks of A-type alkaline affinity. The plutonic rocks belong to the Rio Dourado Intrusive Suite, which is related to the MIS, plus a set of granitic plutons (Ananás, Bom Destino, Triunfo and Sáo Pedro do Iriri), mapped by Vasquez et al. (2008b), and characterized as undifferentiated A-type granites. The volcanic record in this domain is mainly represented by the Santa Rosa Formation, which has a geochemical affinity with the Velho Guilherme Intrusive Suite (Fernandes et al. 2011). Northward of the craton, in the Guyana Shield, this magmatism emplaced the Mapuera Intrusive Suite, which consists of dozens of granitic batholiths and stocks (Madeira, Alalaú, Simão, Rastro, Bom Futuro, São Gabriel, Murauaú granites, etc.), widespread in the Uatumã-Anauá Domain. However, Costi et al. (2000) included Madeira, Água Boa and Europa plutons (previously incorporated into Mapuera Intrusive Suite), located in the Pitinga region, northern of State of Amazonas), in a new unit called Madeira Suite, due to the discovery of slightly younger ages (ca. 1.82 Ga) than those identified in Mapuera Intrusive Suite. In this region, the volcanic rocks related to Mapuera Intrusive Suite occur predominantly in the western portion of Erepecuru-Trombetas Domain, extending westward in Uatumã-Anauá Domain and represented by the Iricoumé Group.

Crystallization ages of $1882 \pm 4$ and $1880 \pm 9$ Ma were obtained by zircon $\mathrm{Pb}$-evaporation method for MIS granites (Vasquez et al. 1999; Lamarão et al. 2002). Additionally, Santos et al. (2001) showed zircon U-Pb SHRIMP ages for the granites of this suite with values between $1877 \pm 12$ and $1872 \pm 4 \mathrm{Ma}$ and identified populations of neoarchean to orosirian inherited zircons. Lamarão et al. (2005) identified a signature of $\mathrm{Nd}$ isotopes for the MIS granites in the eastern portion of the Tapajós Domain, suggesting paleoproterozoic sources ( $\mathrm{T}_{\mathrm{DM}} 2.28$ to $2.23 \mathrm{Ga}$ and $\varepsilon_{\mathrm{Nd}(\mathrm{t})}-0.72$ to -2.45$)$. However, the isotopic signature of some granites belonging to this suite indicates the participation of archean crust in its formation ( $\mathrm{T}_{\mathrm{DM}} 2.53$ to $2.60 \mathrm{Ga}$ and $\varepsilon_{\mathrm{Nd}(\mathrm{t})}-2.84$ to -6.67 , 
Santos et al. 2000) (Tab. 1), which is compatible with the presence of neoarchean inherited zircon crystals, as identified by Santos et al. (2001) in rocks of this same unit. Many plutons of PIS were dated by $\mathrm{Pb}$-evaporation and $\mathrm{U}-\mathrm{Pb}$ zircon methods, and the ages found were between $1891 \pm 3$ and

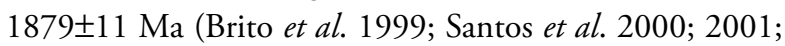

Table 1. Geochronological and isotopic data for paleoproterozoic A-type granites and related volcanic rocks, and PIS rocks from Tapajós and Iriri-Xingu domains, Amazonian Craton.

\begin{tabular}{|c|c|c|c|c|c|c|c|c|}
\hline Geologic unit & Suite & Rock type & Age (Ma) & Method & Ref. & $\varepsilon_{\mathrm{Nd}(\mathrm{t})}$ & $\mathrm{T}_{\mathrm{DM}}(\mathrm{Ga})$ & Ref. \\
\hline \multicolumn{9}{|c|}{ Iriri-Xingu Domain (Central Amazonian Province) } \\
\hline Rio Dourado & RDIS & Syenogranite & $1884 \pm 4$ & $\mathrm{U}-\mathrm{Pb} \mathrm{zr}$ & 10 & & & \\
\hline Rio Dourado & RDIS & Granite & $1876 \pm 39$ & $\mathrm{U}-\mathrm{Pb} \mathrm{zr}$ & 11 & -10.7 to -3.10 & 2.84 to 2.61 & 11 \\
\hline Santa Rosa Formation & - & Ash tuff & $1884 \pm 2$ & $\mathrm{~Pb}-\mathrm{Pb} \mathrm{zr}$ & 12 & \multirow{2}{*}{-11.39 to -5.80} & \multirow{2}{*}{3.12 to 2.56} & \multirow{2}{*}{12} \\
\hline Santa Rosa Formation & - & Rhyolite & $1879 \pm 2$ & $\mathrm{~Pb}-\mathrm{Pb} \mathrm{zr}$ & 12 & & & \\
\hline $\begin{array}{l}\text { A-type Undifferentiated } \\
\text { Granite }\end{array}$ & - & quartz syenite & $1889 \pm 2$ & $\mathrm{~Pb}-\mathrm{Pb} \mathrm{zr}$ & 13 & -8.76 & 2.87 & 13 \\
\hline \multicolumn{9}{|c|}{ Tapajós Domain (Tapajós-Parima Province) } \\
\hline Iriri Group & MIS & Rhyolite & $1888 \pm 2$ & $\mathrm{~Pb}-\mathrm{Pb} \mathrm{zr}$ & 2 & & & \\
\hline Maloquinha granite & MIS & Bt-hb granite & $1882 \pm 4$ & $\mathrm{~Pb}-\mathrm{Pb} \mathrm{zr}$ & 4 & & & \\
\hline Iriri Group & MIS & Rhyodacite & $1888 \pm 2$ & $\mathrm{~Pb}-\mathrm{Pb} \mathrm{zr}$ & 4 & & & \\
\hline Iriri Group & MIS & Rhyolite & $1888 \pm 7$ & $\mathrm{~Pb}-\mathrm{Pb} \mathrm{zr}$ & 3 & & & \\
\hline Maloquinha granite & MIS & Monzogranite & $1877 \pm 12$ & $\mathrm{U}-\mathrm{Pb} \mathrm{zr}$ & 7 & \multirow{4}{*}{-6.67 to -2.84} & \multirow{4}{*}{2.60 to 2.53} & \multirow{4}{*}{5} \\
\hline Maloquinha granite & MIS & Monzogranite & $1874 \pm 7$ & $\mathrm{U}-\mathrm{Pb} \mathrm{zr}$ & 7 & & & \\
\hline Maloquinha granite & MIS & Monzogranite & $1872 \pm 4$ & $\mathrm{U}-\mathrm{Pb} \mathrm{zr}$ & 7 & & & \\
\hline Maloquinha granite & MIS & Alaskite & $1899 \pm 25$ & $\mathrm{U}-\mathrm{Pb} \mathrm{zr}$ & 7 & & & \\
\hline Iriri Group & MIS & - & $1870 \pm 8$ & $\mathrm{U}-\mathrm{Pb} \mathrm{zr}$ & 7 & -1.37 & 2.45 & 5 \\
\hline Maloquinha granite & MIS & Bt monzogranite & $1880 \pm 9$ & $\mathrm{~Pb}-\mathrm{Pb} z \mathrm{r}$ & 8 & -2.45 to -0.72 & 2.28 to 2.23 & 9 \\
\hline Moraes Almeida Formation & MIS & Rhyolite & $1890 \pm 6$ & $\mathrm{~Pb}-\mathrm{Pb} \mathrm{zr}$ & 8 & \multirow{3}{*}{-3.05 to -1.98} & \multirow{3}{*}{2.44 to 2.29} & \multirow{3}{*}{9} \\
\hline Moraes Almeida Formation & MIS & Trachyte & $1881 \pm 4$ & $\mathrm{~Pb}-\mathrm{Pb} \mathrm{zr}$ & 8 & & & \\
\hline Moraes Almeida Formation & MIS & Ignimbrite & $1875 \pm 4$ & $\mathrm{~Pb}-\mathrm{Pb} \mathrm{zr}$ & 8 & & & \\
\hline Mamoal granite & MIS & - & - & - & - & -5.01 to -0.89 & 2.60 to 2.20 & 14 \\
\hline Dalpaiz granite & MIS & - & - & - & - & -2.07 to -0.76 & 2.41 to 2.22 & 14 \\
\hline Serra Alta granite & MIS & - & - & - & - & -3.85 to -3.85 & 2.46 & 14 \\
\hline Parauari granite & PIS & Syenogranite & $1883 \pm 4$ & $\mathrm{U}-\mathrm{Pb} \mathrm{zr}$ & 7 & & & \\
\hline Parauari granite & PIS & - & $1883 \pm 8$ & $\mathrm{~Pb}-\mathrm{Pb} \mathrm{zr}$ & 1 & & & \\
\hline Parauari granite & PIS & Granite & $1883 \pm 2$ & $\mathrm{~Pb}-\mathrm{Pb} \mathrm{zr}$ & 6 & & & \\
\hline Parauari granite & PIS & Monzogranite & $1879 \pm 11$ & $\mathrm{U}-\mathrm{Pb} \mathrm{zr}$ & 5 & & & \\
\hline Jardim do Ouro granite & PIS & Hb-bt monzogranite & $1880 \pm 3$ & $\mathrm{~Pb}-\mathrm{Pb} \mathrm{zr}$ & 8 & -1.82 & 2.32 & 9 \\
\hline Younger São Jorge granite & PIS & Hb-bt monzogranite & $1891 \pm 3$ & $\mathrm{~Pb}-\mathrm{Pb} \mathrm{zr}$ & 8 & -5.21 and -3.42 & 2.43 and 2.32 & 9 \\
\hline
\end{tabular}

References: 1) Brito et al. (1999), 2) Dall'Agnol et al. (1999b), 3) Moura et al. (1999), 4) Vasquez et al. (1999), 5) Santos et al. (2000), 6) Klein \& Vasquez (2000), 7) Santos et al. (2001), 8) Lamarão et al. (2002), 9) Lamarão et al. (2005), 10) Barros et al. (2006), 11) Barros et al. (2011), 12) Fernandes et al. (2011), 13) Semblano et al. (2016), 14) this work.

RDIS: Rio Dourado Intrusive Suite; MIS: Maloquinha Intrusive Suite; PIS: Parauari Intrusive Suite; Bt: biotite; Hb: hornblende; zr: zircon. 
Klein and Vasquez 2000), including Younger São Jorge and Jardim do Ouro granites, dated by Lamarão et al. (2002). The $\mathrm{Nd}$ isotopic signature obtained in these two plutons ( $\mathrm{T}_{\mathrm{DM}}$ of 2.43 to $2.32 \mathrm{Ga}$ and $\varepsilon_{\mathrm{Nd}(\mathrm{t})}-5.21$ to -1.82 ) (Tab. 1) suggests interaction of juvenile source with an older crustal one (Lamarão et al. 2005). Rare Sm-Nd $\mathrm{T}_{\mathrm{DM}}$ neoarchean ages are recorded in the Tapajós Domain rocks, which has mainly paleoproterozoic sources. Eastward, they dominate igneous rocks with typical crustal Archean sources, which characterize the Iriri-Xingu Domain (Fig. 1).

\section{STUDY AREA}

The study area we focus on here is located in eastern portion of the Tapajós Domain, southern of the TapajósParima Province. Geographically, it is located in Itaituba city, southwestern of the state of Pará. The eastern portion of the area is cut by Novo and Jamanxim rivers and BR-163, which are important connection routes from headquarters Itaituba city (north) to Moraes Almeida district, where the study area is located. This area is included in the SB.21Z-A-II (São Domingos) and SB.21-Z-A-III (Jardim do Ouro) 1:100,000 sheets, between 55०30'W and 56 $17^{\prime} \mathrm{W}$ longitudes, and $6^{\circ} S$ and $6^{\circ} 21^{\prime} S$ latitudes (Fig. 2). Figure 2 also shows the sampled points for geochemical and isotopic (Sm-Nd whole rock) study on the five plutons studied here: Dalpaiz, Mamoal, Igarapé Tabuleiro, Serra Alta e Igarapé Salustiano, established by Vasquez et al. (2014a; $2014 \mathrm{~b}$ ) with gamma spectrometry and magnetometry airborne geophysical support.

\section{PETROGRAPHY}

Petrographic studies were performed in four of the five plutons covered: Mamoal, Dalpaiz, Serra Alta and Igarapé Salustiano granites (Fig. 2). The petrography of the Igarapé Tabuleiro granite was presented by Lamarão (2001), who named it as Maloquinha granite. The rocks of Mamoal, Dalpaiz and Serra Alta plutons, belonging to the MIS, have reddish pink to pinkish gray color, whereas the Igarapé Salustiano granite (PIS) is greyish. All units are dominantly hololeucocratic.

Detailed mineralogical and textural analyses in each sample were performed. Phases and mineral parageneses, morphology, contact relationships among minerals and their zoning and alterations were identified. The anortite (An) content of the plagioclases was estimated through optical determination. The modal content of the samples were

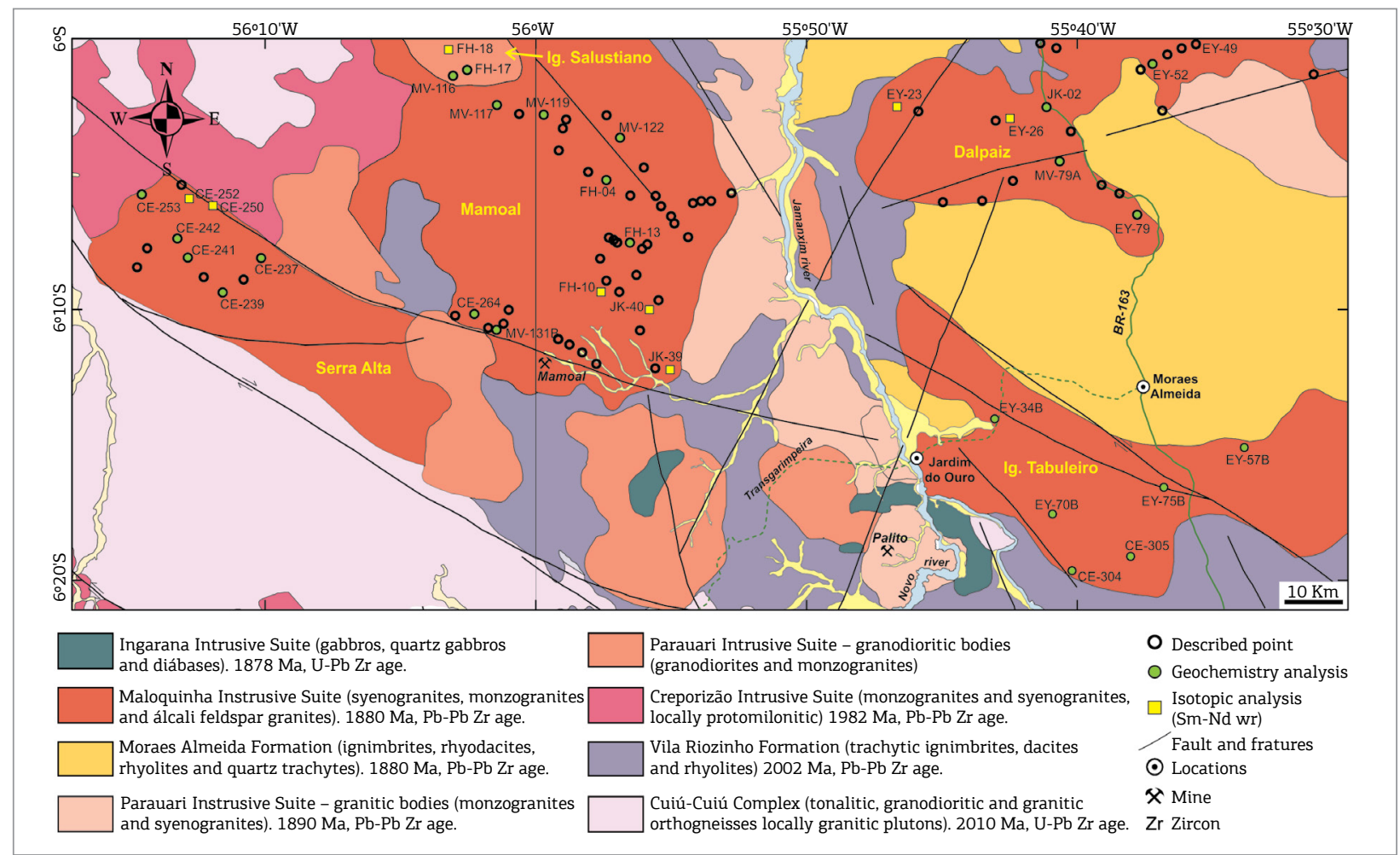

Figure 2. Geological map of the study area with rocks samples of the study granites (modified from Vasquez et al. 2014a; 2014b). 
plotted on the Streckeisen (1976) QAP diagram (Fig. 3), which allowed the classification of the rock sets according to the International Union of Geological Sciences (IUGS) proposed nomenclature. Table 2 summarizes the modal content of essential, mafic and varietal minerals, and the occurrence of accessory and secondary minerals in each one of the described facies from studied plutons.

\section{Mamoal granite}

The Mamoal granite was split into three petrographic facies: biotite-amphibole monzogranite (BAMzG), biotite-amphibole syenogranite (BASG), and biotite-alkali feldspar granite (BAFG). These rocks have hypidiomorphic inequigranular texture and are medium- to coarsegrained. Locally, we observed porphyritic textures with a fine-grained matrix (Fig. 4A) and myrmekitic intergrowths, as well as intergranular albites. Plagioclase occurs as prismatic and subhedral crystals with irregular contacts and subordinately straight, especially between quartz and biotite. Its dominant composition is oligoclase $\left(\mathrm{An}_{12-30}\right)$, but some samples of BAMzG facies have andesitic composition $\left(\mathrm{An}_{30-34}\right)$. The plagioclase comprises less than $1 \%$ modal content of some BAFG facies samples. The alkali feldspar (orthoclase) occurs predominantly as subhedral to anhedral prismatic and perthitic crystals, particularly in BAFG facies, and exhibits well developed pertites (Fig. 4B). Inclusions of plagioclase and quartz were observed in some crystals. Furthermore, they form irregular contacts among them and are predominantly irregular and locally straight with quartz. The varietal minerals are biotite $(0.5-5 \%)$ and amphibole $(<3 \%)$. Allanite is an accessory mineral that has been identified in BAMzG facies and displays subhedral to euhedral crystals, strongly zoned, metamictizated, and they are mostly associated to opaque minerals and amphibole (Fig. 4C). The secondary minerals are representeded by clay minerals, sericite, epidote, chlorite, muscovite, biotite and opaques.

\section{Dalpaiz granite}

The Dalpaiz granite was split into two facies, biotite-amphibole monzogranite (BAMzG) and biotite syenogranite (BSG). This pluton is composed of rocks of hypidiomorphic inequigranular texture and is fine- to medium-grained. Locally, inter-granular albite and myrmekitic intergrowth can be observed. Quartz is granular with an anhedral to subhedral habit and weak to strong undulatory extinction.

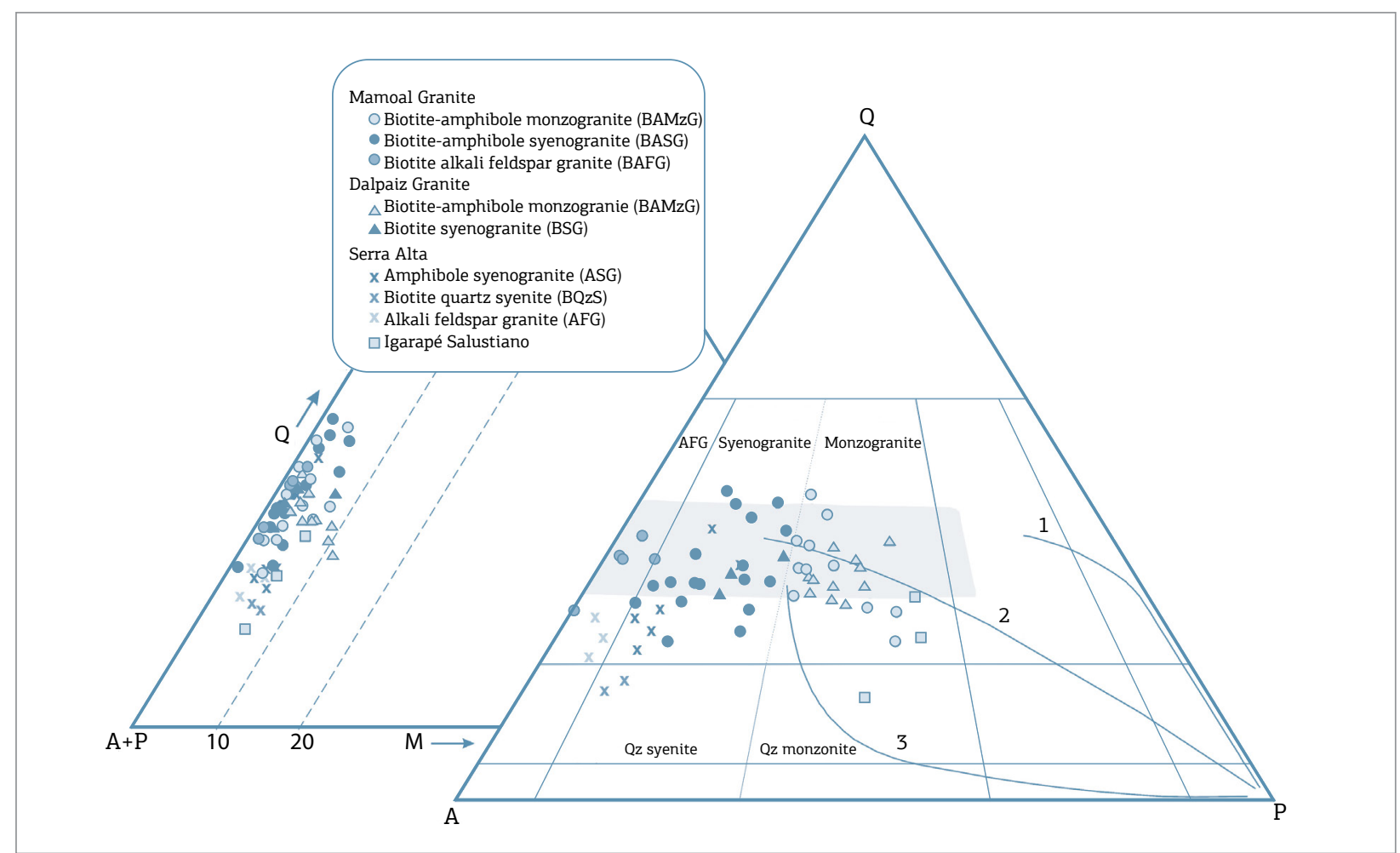

Figure 3. Q-A-P and Q-(A+P)-M diagrams (Streckeisen 1976) showing the mineralogical modal composition of Mamoal, Dalpaiz, Serra Alta and Igarapé Salustiano plutons. Lines 1, 2 and 3, respectively, represent the trends of tonalitic-trondhjemitic calc-alkaline, granodioritic calc-alkaline and shoshonitic series. The grey field represents the granitoids formed by crustal melting (Lameyre and Bowden 1982). 
Occasionally, it displays embayment features, whose edges are intergrown with alkali feldspar (Fig. 4D). It also occurs the forming granophyric intergrowth (radial fringe type) in alkali feldspar crystals (Fig. 4E). Plagioclase (oligoclase type, $\mathrm{An}_{12-28}$ ) occurs as subhedral and subordinate euhedral prismatic crystals. They show normal compositional zoning with calcic core (pointed out by alteration). Some of their crystals show penetrative contact within alkali feldspar. Alkali feldspar crystals, orthoclase type, are tabular, predominantly prismatic and sometimes occur with interstitial aspect or perthitic intergrowth. They form irregular contacts among themselves and other minerals, locally straight with quartz. The varietal minerals are biotite $(<7 \%)$ and amphibole $(<2 \%)$, and the secondary

Table 2. Mineralogical contents of Mamoal, Dalpaiz, Igarapé Tabuleiro, Serra Alta and Igarapé Salustiano plutons.

\begin{tabular}{|c|c|c|c|c|c|c|c|}
\hline Pluton & Facies & $\begin{array}{l}\text { Essential } \\
\text { minerals } \\
\text { (modal \%) }\end{array}$ & $\begin{array}{c}\text { Mafic } \\
\text { minerals } \\
\text { (modal \%) }\end{array}$ & $\begin{array}{c}\text { Varietal } \\
\text { minerals } \\
\text { (modal \%) }\end{array}$ & $\begin{array}{l}\text { Accessory } \\
\text { minerals }\end{array}$ & $\begin{array}{l}\text { Secondary } \\
\text { minerals }\end{array}$ & Plagioclase \\
\hline \multirow{3}{*}{ Mamoal } & BAMzG & $\begin{array}{c}\mathrm{Qz}(24-46) \\
\mathrm{Pl}(20-42) \\
\text { K-fsp (32-43) }\end{array}$ & $0.1-7$ & $\begin{array}{l}\mathrm{Bt}(<2.5) \\
\mathrm{Hb}(<2)\end{array}$ & Ttn, Aln, Opq, Ap, Zr & $\begin{array}{l}\text { Ser, Ep, Chl, } \\
\text { Opq, Cm }\end{array}$ & $\begin{array}{l}\text { Oligoclase/ } \\
\text { Andesine }\end{array}$ \\
\hline & BASG & $\begin{array}{c}\mathrm{Qz}(24-47) \\
\mathrm{Pl}(5-22) \\
\text { K-fsp (37-62) }\end{array}$ & $0.5-6$ & $\begin{array}{c}\mathrm{Bt}(0.5-5) \\
\mathrm{Hb}(<2)\end{array}$ & Ap, Zr, Opq, Ttn & $\begin{array}{l}\text { Ser, Ep, Chl, } \\
\text { Ms, Bt, Cm }\end{array}$ & Oligoclase \\
\hline & BAFG & $\begin{array}{c}\text { Qz (39-28) } \\
\text { Pl }(<8) \\
\text { K-fsp }(58-71)\end{array}$ & $<1$ & Bt $(<2)$ & Ap, Zr, Opq & $\begin{array}{l}\text { Ser, Ms, Ep, } \\
\text { Cm }\end{array}$ & $\begin{array}{l}\text { (Albite) } \\
\text { Oligoclase }\end{array}$ \\
\hline \multirow{2}{*}{ Dalpaiz } & BAMzG & $\begin{array}{c}\text { Qz (28-38) } \\
\text { Pl (25-33) } \\
\text { K-fsp (27-37) }\end{array}$ & $2-11$ & $\begin{array}{l}\mathrm{Bt}(4-7) \\
\mathrm{Hb}(<5)\end{array}$ & Ttn, Opq, Ap, Zr & $\begin{array}{l}\text { Ser, Ms, Chl, } \\
\text { Bt, Opq, Cm }\end{array}$ & Oligoclase \\
\hline & BSG & $\begin{array}{c}\text { Qz (31-36) } \\
\text { Pl (16-21) } \\
\text { K-fsp (41-52) }\end{array}$ & $1-2$ & Bt $(\sim 2)$ & Ap, Aln, Opq, Zr, Ep & $\begin{array}{c}\text { Ser, Chl, Opq, } \\
\text { Cm }\end{array}$ & Oligoclase \\
\hline \multirow{3}{*}{$\begin{array}{l}\text { Igarapé } \\
\text { Tabuleiro }^{\mathrm{a}}\end{array}$} & BLMzG/SG & $\begin{array}{c}\mathrm{Qz}(24-47) \\
\mathrm{Pl}(8-24) \\
\text { K-fsp (35-56) }\end{array}$ & $1-4$ & $\mathrm{Bt}(<3.5)$ & Ap, Aln, Opq, Zr & $\begin{array}{l}\text { Ser, Chl, Ms, } \\
\text { Opq, Ttn, } \\
\text { Fl, Cb }\end{array}$ & $\begin{array}{l}\text { Oligoclase/ } \\
\text { Albite }\end{array}$ \\
\hline & $\mathrm{ABQM}$ & $\begin{array}{c}\text { Qz (19) } \\
\text { Pl (39) } \\
\text { K-fsp (42) }\end{array}$ & $\sim 6$ & $\begin{array}{l}\mathrm{Bt}(2.2) \\
\mathrm{Hb}(1.1)\end{array}$ & Ap, Zr, Opq & $\begin{array}{l}\text { Ser, Chl, Ep, } \\
\text { Ttn, Fl, Cm }\end{array}$ & - \\
\hline & BQS & $\begin{array}{c}\text { Qz (17) } \\
\text { Pl (18) } \\
\text { K-fsp (65) }\end{array}$ & $\sim 4$ & $\mathrm{Bt}(2.4)$ & Ap, Zr, Opq & $\begin{array}{l}\text { Ser, Chl, Ttn, } \\
\text { Fl, Cm }\end{array}$ & - \\
\hline \multirow{3}{*}{ Serra Alta } & ASG & $\begin{array}{c}\text { Qz (23-42) } \\
\text { Pl (10-17) } \\
\text { K-fsp (47-66) }\end{array}$ & $2.5-6$ & $\begin{array}{l}\mathrm{Bt}(<1.8) \\
\mathrm{Hb}(1-2)\end{array}$ & Opq, Ep, Zr, Ap, Aln & $\begin{array}{l}\text { Ser, Ep, Opq, } \\
\quad \text { Cb, Cm }\end{array}$ & $\begin{array}{l}\text { Oligoclase/ } \\
\text { Andesine }\end{array}$ \\
\hline & BQzS & $\begin{array}{c}\text { Qz (18-19) } \\
\text { Pl (9-11) } \\
\text { K-fsp (69-72) }\end{array}$ & $5-7$ & $\begin{array}{l}\text { Bt }(2-4) \\
\mathrm{Hb}(<2)\end{array}$ & $\mathrm{Ep}, \mathrm{Ap}, \mathrm{Zr}$ & $\begin{array}{l}\text { Ep, Ser, Ms, } \\
\text { Opq, Cm }\end{array}$ & Oligoclase \\
\hline & AFG & $\begin{array}{c}\text { Qz (21-24) } \\
\text { Pl (5-6) } \\
\text { K-fsp (71-73) }\end{array}$ & $2-5$ & $\begin{array}{l}\mathrm{Bt}(1-1.5) \\
\mathrm{Hb}(<2.5)\end{array}$ & Ap, Ep, Ms & Ser, Opq, Cm & $\begin{array}{l}\text { Albite/ } \\
\text { Oligoclase }\end{array}$ \\
\hline $\begin{array}{l}\text { Igarapé } \\
\text { Salustiano }\end{array}$ & BAMzG & $\begin{array}{c}\text { Qz (16-31) } \\
\text { Pl (41-44) } \\
\text { K-fsp (29-42) }\end{array}$ & $6-7$ & $\begin{array}{l}\mathrm{Bt}(5-6) \\
\mathrm{Hb}(<1)\end{array}$ & Ttn, Opq, Ap, Zr & Ser, Chl, Cm & $\begin{array}{l}\text { Oligoclase/ } \\
\text { Andesine }\end{array}$ \\
\hline
\end{tabular}

Petrographic facies: BAMzG) biotite-amphibole monzogranite; BASG) biotite-amphibole syenogranite; BAFG) biotite alkali feldspar granite; BSG) biotite syenogranite; BLMzG/SG) biotite leucomonzogranite to leucosienogranite; $A B Q M$ ) amphibole-biotite quartz monzonite; BQS) biotite quartz sienite; ASG) amphibole syenogranite; BQzS) biotite quartz syenite; AFG) alkali feldspar granite.

Minerals: Aln) allanite; $\mathrm{Ap}$ ) apatite; $\mathrm{Bt}$ ) biotite; $\mathrm{Cb}$ ) carbonate; Chl) chlorite; $\mathrm{Cm}$ ) clay minerals; Ep) epidote; Fl) fluorite; $\mathrm{K}$-fsp) alcali feldspar; $\mathrm{Hb}$ ) hornblende; Ms) muscovite; Opq) opaque; Pl) plagioclase; Qz) quartz; Ser) sericite; Ttn) titanite; Zr) zircon.

${ }^{a}$ Data from Lamarão (2001). 
minerals are described as sericite, clay minerals, chlorite, biotite, muscovite and opaques.

\section{Serra Alta granite}

The Serra Alta granite encompasses three petrographic facies: amphibole syenogranite (ASG), biotite quartz syenite $(\mathrm{BQzS})$ and alkaline feldspar granite (AFG). These rocks have hypidiomorphic inequigranular texture and mediumto coarse-grained in the ASG and AFG facies, and fine- to medium-grained in the BQzS facies. The ASG facies also includes rocks with a porphyritic texture with a fine-grained quartz-feldspathic matrix. In the AFG facies, quartz intergrown into alkali feldspar is common, forming a granophyric texture.
Plagioclase appears as subhedral prismatic crystals, showing normal zoning. Their anorthite contents usually have $\mathrm{An}_{18}$ to $\mathrm{An}_{32}$ (oligoclase to andesine), but in the AFG facies there are also rocks with albitic plagioclase. Their contacts are regular with other crystals and interpenetrating especially with quartz and biotite. Locally, they occur included in alkali feldspar. Alkali feldspar displays anhedral to subhedral strongly perthitic tabular crystals, especially in the AFG facies. It occurs mostly as orthoclase, and it is possible to identify microcline in the BQzG facies. In the ASG facies, allanite crystals are associated with epidote (Fig. $4 \mathrm{~F}$ ) and opaque minerals replacing amphibole (Fig. 4G). The remaining secondary minerals are clay minerals, sericite, epidote, carbonate and muscovite.
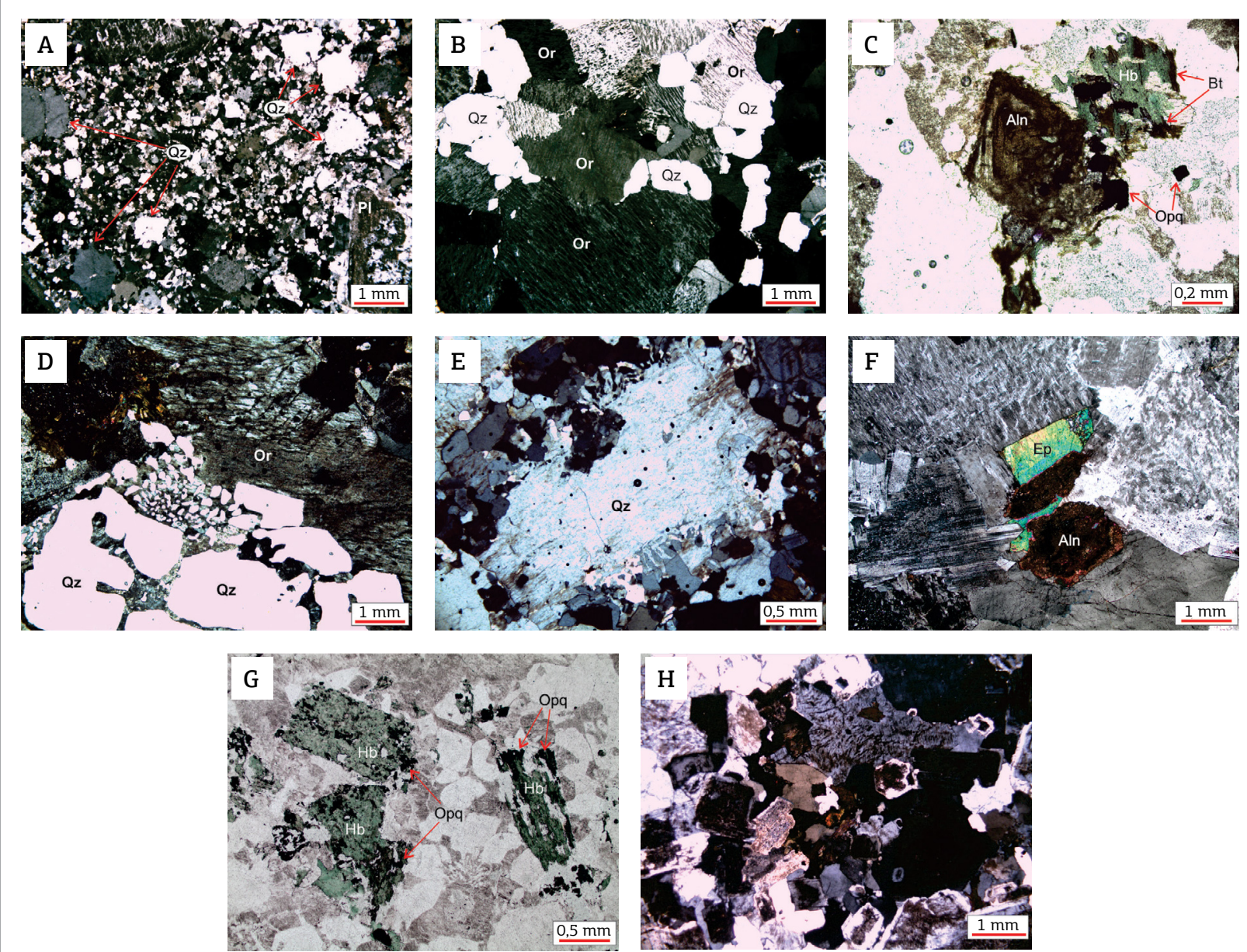

Aln: allanite; Bt: biotite; Hb: hornblende; Opq: opaque; Or: orthoclase; Pl: plagioclase; Qz: quartz.

Figure 4. Textural aspects photomicrographs of the studied rocks. (A) porphyritic texture in BAMzG facies rock of the Mamoal granite; (B) well developed pertitas in BFAG facies of the Mamoal granite; (C) allanite crystal associated with opaque minerals and amphibole, which presents break-up to biotite in BAMzG facies of the Mamoal granite; (D) bight in quartz crystals with their edges intergrown in alkali feldspar of the BAMzG facies of the Dalpaiz granite; (E) alkali feldspar crystal showing radial fringe type granofiric intergrowth with quartz in BSG facies of the Dalpaiz granite; (F) allanite crystals associated to epidote in ASG facies of the Serra Alta granite; (G) opaque mineral replacing amphibole crystals in ASG facies of the Serra Alta granite; $(\mathrm{H})$ representative isotropic textural aspect of the Igarapé Salustiano granite. Images are under cross-polarized light. 


\section{Iguarapé Salustiano granite}

This pluton has hypidiomorphic to idiomorphic inequigranular texture, and is medium- to coarse-grained. Large plagioclase and alkali feldspar crystals (6 to $9 \mathrm{~mm}$ ) are dispersed throughout the rock. The plagioclase is prismatic, subhedral to euhedral, and its composition ranges from oligoclase to andesine $\left(\mathrm{An}_{25-34}\right)$. It shows dominant regular contact with other crystals and is weakly zoned. Alkali feldspar is prismatic to tabular and subhedral. Its contacts are irregular, especially among itselves and with quartz. In some crystals it can be seen the double albite-pericline twin, diagnostic of microcline. More developed alkali feldspar crystals have inclusions of plagioclase and opaque minerals. Varietal minerals are biotite (5-6\%) and amphibole $(<1 \%)$, whereas the secondary are sericite, clay minerals and chlorite. Any apparent textural feature of anisotropy was not identified in these rocks (Fig. $4 \mathrm{H}$ ).

\section{GEOCHEMISTRY}

\section{Analytical procedures}

Chemical analyses of 29 studied rock samples (Tab. 3) were performed at SGS Geosol Laboratory and provided to this work by Companhia de Pesquisa de Recursos Minerais (CPRM) - Brazilian Geological Survey (Superintendência Regional de Belém - SUREG-BE). Major and minor elements were analyzed $\left(\mathrm{SiO}_{2}, \mathrm{Al}_{2} \mathrm{O}_{3}, \mathrm{Fe}_{2} \mathrm{O}_{3}, \mathrm{MgO}, \mathrm{CaO}\right.$, $\mathrm{Na}_{2} \mathrm{O}, \mathrm{K}_{2} \mathrm{O}, \mathrm{TiO}_{2}$ and $\mathrm{P}_{2} \mathrm{O}_{5}$ ) by Inductively Coupled Plasma Atomic Emission Spectroscopy (ICP-ES), trace (Rb, Sr, Ba, $\mathrm{Ga}, \mathrm{Hf}, \mathrm{Y}, \mathrm{Zr}, \mathrm{Nb}, \mathrm{Ta}, \mathrm{U}$ and Th), including REE (La, Ce, $\mathrm{Nd}, \mathrm{Sm}, \mathrm{Eu}, \mathrm{Gd}, \mathrm{Dy}, \mathrm{Ho}, \mathrm{Er}, \mathrm{Yb}$ and Lu), by Inductively Coupled Plasma Mass Spectrometry (ICP-MS). Geochemical classification of the studied plutons followed the procedures drafted by Ragland (1989) and Rolisson (1993) using different diagrams (Shand 1951; Whalen et al. 1987; Eby 1992; Pearce 1996; Frost et al. 2001), aiming to geochemically characterize the involved processes in magmatic evolution, granitic typology, environment and geotectonic signature of the studied rocks.

\section{Results}

The Dalpaiz, Mamoal, Igarapé Tabuleiro and Serra Alta plutons belonging to the MIS have a high content of $\mathrm{SiO}_{2}$ (69.1-77.1\%), and the Igarapé Salustiano granite, belonging to PIS, has uniform composition in two of the three analyzed samples with $\mathrm{SiO}_{2}$ between 74.2 and $76.7 \%$ and a sample (MV-116) with lower value (67.1\%). The MIS alkalis content $\left(\mathrm{Na}_{2} \mathrm{O}+\mathrm{K}_{2} \mathrm{O}=7.8-11.3 \%\right)$ is greater than PIS $\left(\mathrm{Na}_{2} \mathrm{O}+\mathrm{K}_{2} \mathrm{O}=\right.$ 7.1-7.8\%). In $\mathrm{K}_{2} \mathrm{O}$ vs. $\mathrm{SiO}_{2}$ diagram (Fig. 5A) MIS samples fell into high-K and shoshonite fields, and the PIS samples plotted as high- to medium-K, indicating that the PIS has $\mathrm{Na}_{2} \mathrm{O}$ content higher than $\mathrm{K}_{2} \mathrm{O}$ compared to its high alkalis content. Fe-index vs. $\mathrm{SiO}_{2}$ (Fig. 5B) and Modified Alkali-Lime Index (MALI) vs. $\mathrm{SiO}_{2}$ (Fig. 5C) from Frost et al. (2001) also pointed out the contrast between MIS and Igarapé Salustiano pluton from PIS. The MIS shows high Fe-index values (0.820.99) plotting in A-type granite field as ferroan, and the PIS samples (Fe-index $=0.75-0.77$ ) are magnesian plotting mostly in the cordilleran granites field. The MIS has MALI $\left(\mathrm{Na}_{2} \mathrm{O}+\mathrm{K}_{2} \mathrm{O}-\mathrm{CaO}\right)$ values considerably higher than PIS, and in the MALI vs. $\mathrm{SiO}_{2}$ diagram MIS falls in the alkalic and alkalic-calcic fields, whereas PIS in the calc-alkalic and calcic fields. A/NK vs. A/CNK diagram (Fig. 5D) shows that both MIS and PIS are peraluminous to metaluminous, with A/CNK ratios ranging from 0.91 to 1.12 for the MIS, and 0.94 to 1.04 for PIS rocks. However, PIS samples have A/NK ratios slightly bigger than MIS, but both with $\mathrm{A} / \mathrm{NK}>1.0$.

In $\mathrm{Rb} v$ s. $(\mathrm{Y}+\mathrm{Nb}$ ) diagram (Fig. $5 \mathrm{E})$, both MIS and PIS samples exhibit high $\mathrm{Rb}$ contents, however the MIS rocks plot in within-plate or post-collisional granitoids field (Pearce 1996), and the PIS in the syn-collisional granitoids field. In $\left(\mathrm{K}_{2} \mathrm{O}+\mathrm{Na}_{2} \mathrm{O}\right) / \mathrm{CaO}$ vs. $(\mathrm{Zr}+\mathrm{Nb}+\mathrm{Ce}+\mathrm{Y})$ diagram from Whallen et al. (1987) (Fig. 5F) it is observed that the MIS samples fall dominantly in the A-type granites field, with some samples extending to the fractionated I-type granites field, whereas PIS samples falls in the not fractionated I- and S-type granites field. MIS has medium to high values of $\mathrm{Zr}+\mathrm{Nb}+$ $\mathrm{Ce}+\mathrm{Y}(223-840 \mathrm{ppm})$ in relation to PIS (190-285 ppm).

In spidergram (Fig. 6), MIS shows enrichment in the Rb, $\mathrm{Th}, \mathrm{U}$ and $\mathrm{K}$ elements, and depletion of $\mathrm{Ba}, \mathrm{Nb}, \mathrm{Sr}, \mathrm{P}$ and $\mathrm{Ti}$, whereas the PIS is enriched in $\mathrm{Rb}, \mathrm{Ba}$, Th and $\mathrm{K}$ with a slight negative anomaly of $\mathrm{U}$ and depleted in $\mathrm{Nb}, \mathrm{P}$ and $\mathrm{Ti}$. Variations in the $\mathrm{Rb}, \mathrm{Ba}, \mathrm{Sr}$ and Ti contents are mainly attributed to differences in the rock-forming minerals contents. The high $\mathrm{Rb}$ contents and low $\mathrm{Sr}$ and $\mathrm{Ba}$ from MIS, as well as high $\mathrm{Rb}$ and $\mathrm{Ba}$ contents, and low Ti from PIS were caused by fractional crystallization of alkali feldspar, plagioclase and biotite. Both units showed quite consistent and reproducible patterns with each other.

Total REE content from MIS (200-694 ppm) is significantly higher than PIS (133-239 ppm). In chondrite-normalized parameter (Fig. 7) light rare earth elements (LREE) is enriched relative to heavy rare earth elements (HREE) in both units. In MIS, the fractionation of LREE $\left[(\mathrm{La} / \mathrm{Sm})_{\mathrm{N}}\right]$ showed values between 2.3 and 11.9, and HREE $\left[(\mathrm{Gd} / \mathrm{Yb})_{\mathrm{N}}\right]$ from 0.7 to 2.1 , creating a scarped pattern to the right of LREE, whereas HREE show a subhorizontal pattern, with total fractionation of the REE $\left[(\mathrm{La} / \mathrm{Yb})_{\mathrm{N}}\right]$ ranging from 2.7 to 18.2. Similarly, PIS shows a remarkable fractionation of the LREE $\left[(\mathrm{La} / \mathrm{Sm})_{\mathrm{N}}=5.5\right.$ to 7.2$]$ relative to $\operatorname{HREE}\left[(\mathrm{Gd} / \mathrm{Yb})_{\mathrm{N}}=2.3\right.$ to 2.7$]$, with total fractionation 
Table 3. Major (wt.\%) and trace (ppm) elements data for Maloquinha Intrusive Suite (MIS) and Parauari Intrusive Suite (PIS) granitoids.

\begin{tabular}{|c|c|c|c|c|c|c|c|c|c|c|c|c|c|c|}
\hline \multirow{4}{*}{$\begin{array}{l}\text { Unit rock } \\
\text { Pluton name } \\
\text { Facies/Lithotype } \\
\text { Sample }\end{array}$} & \multicolumn{14}{|c|}{ Maloquinha Intrusive Suite } \\
\hline & \multirow{2}{*}{\multicolumn{6}{|c|}{$\begin{array}{c}\text { Dalpiz granite } \\
\text { BAMzG }\end{array}$}} & \multicolumn{8}{|c|}{ Mamoal granite } \\
\hline & & & & & & & \multicolumn{3}{|c|}{ BAMzG } & \multicolumn{3}{|c|}{ BASG } & \multicolumn{2}{|c|}{ BAFG } \\
\hline & $\begin{array}{c}\text { EY- } \\
26\end{array}$ & $\begin{array}{l}\text { EY- } \\
23\end{array}$ & $\begin{array}{c}\text { MV- } \\
79\end{array}$ & $\begin{array}{l}\text { JK- } \\
02\end{array}$ & $\begin{array}{c}\text { EY- } \\
52\end{array}$ & $\begin{array}{c}\text { EY- } \\
79\end{array}$ & $\begin{array}{c}\text { FH- } \\
13\end{array}$ & $\begin{array}{l}\text { MV- } \\
119\end{array}$ & $\begin{array}{l}\text { MV- } \\
122\end{array}$ & $\begin{array}{c}\text { JK- } \\
39\end{array}$ & $\begin{array}{c}\text { MV- } \\
\text { 131B }\end{array}$ & $\begin{array}{l}\text { CE- } \\
264\end{array}$ & $\begin{array}{c}\text { FH- } \\
04\end{array}$ & $\begin{array}{c}\text { MV- } \\
117\end{array}$ \\
\hline \multicolumn{15}{|c|}{ Major elements (wt.\%) } \\
\hline $\mathrm{SiO}_{2}$ & 71.12 & 71.20 & 73.50 & 74.39 & 75.57 & 77.21 & 70.42 & 72.84 & 77.00 & 72.66 & 72.78 & 73.51 & 73.88 & 74.47 \\
\hline $\mathrm{TiO}_{2}$ & 0.23 & 0.28 & 0.14 & 0.19 & 0.19 & 0.07 & 0.37 & 0.21 & 0.26 & 0.17 & 0.37 & 0.23 & 0.09 & 0.16 \\
\hline $\mathrm{Al}_{2} \mathrm{O}_{3}$ & 16.04 & 16.77 & 12.63 & 12.45 & 13.17 & 12.39 & 13.51 & 13.96 & 14.57 & 12.69 & 15.21 & 12.13 & 14.01 & 13.27 \\
\hline $\mathrm{Fe}_{2} \mathrm{O}_{3}$ & 3.08 & 3.32 & 1.92 & 2.41 & 2.52 & 1.64 & 2.72 & 1.85 & 1.81 & 1.62 & 3.04 & 1.93 & 1.38 & 1.70 \\
\hline $\mathrm{MnO}$ & 0.10 & 0.12 & 0.06 & 0.06 & 0.04 & 0.02 & 0.06 & 0.05 & 0.06 & 0.05 & 0.11 & 0.05 & - & 0.02 \\
\hline $\mathrm{MgO}$ & 0.28 & 0.53 & 0.16 & 0.19 & 0.12 & 0.03 & 0.47 & 0.22 & 0.25 & 0.07 & 0.33 & 0.18 & 0.01 & 0.10 \\
\hline $\mathrm{CaO}$ & 1.02 & 1.84 & 0.70 & 0.69 & 0.50 & 0.28 & 1.19 & 0.78 & 0.58 & 0.18 & 0.98 & 0.43 & 0.08 & 0.53 \\
\hline $\mathrm{Na}_{2} \mathrm{O}$ & 4.77 & 4.84 & 3.75 & 4.00 & 4.22 & 4.08 & 4.12 & 3.96 & 4.30 & 3.71 & 4.21 & 3.47 & 4.79 & 3.30 \\
\hline $\mathrm{K}_{2} \mathrm{O}$ & 5.77 & 4.57 & 4.82 & 5.03 & 4.94 & 4.59 & 5.44 & 4.98 & 4.85 & 5.53 & 5.52 & 4.47 & 5.32 & 5.43 \\
\hline $\mathrm{P}_{2} \mathrm{O}_{5}$ & - & 0.05 & - & 0.03 & - & - & 0.10 & 0.03 & 0.07 & 0.02 & 0.07 & 0.03 & 0.01 & 0.02 \\
\hline LOI & 0.11 & 0.17 & 0.24 & 0.38 & 0.19 & 0.11 & 0.44 & 0.22 & 0.39 & 0.42 & 0.34 & 0.66 & 0.23 & 0.18 \\
\hline Total & 102.5 & 103.69 & 97.93 & 99.82 & 101.47 & 100.43 & 98.84 & 99.10 & 104.14 & 97.12 & 102.96 & 97.09 & 99.81 & 99.18 \\
\hline $\mathrm{A} / \mathrm{CNK}^{\mathrm{a}}$ & 1.01 & 1.03 & 1.00 & 0.94 & 1.00 & 1.02 & 0.91 & 1.05 & 1.09 & 1.02 & 1.04 & 1.07 & 1.02 & 1.08 \\
\hline $\mathrm{A} / \mathrm{NK}^{\mathrm{b}}$ & 1.14 & 1.30 & 1.11 & 1.04 & 1.07 & 1.06 & 1.07 & 1.17 & 1.18 & 1.05 & 1.18 & 1.15 & 1.03 & 1.17 \\
\hline Fe-index ${ }^{c}$ & 0.91 & 0.85 & 0.92 & 0.92 & 0.95 & 0.98 & 0.84 & 0.88 & 0.87 & 0.95 & 0.89 & 0.91 & 0.99 & 0.94 \\
\hline $\mathrm{K}_{2} \mathrm{O}+\mathrm{Na}_{2} \mathrm{O}$ & 10.54 & 9.41 & 8.57 & 9.03 & 9.16 & 8.67 & 9.56 & 8.94 & 9.15 & 9.24 & 9.73 & 7.94 & 10.11 & 8.73 \\
\hline $\mathrm{K}_{2} \mathrm{O} / \mathrm{Na}_{2} \mathrm{O}$ & 1.21 & 0.94 & 1.29 & 1.26 & 1.17 & 1.13 & 1.32 & 1.26 & 1.13 & 1.49 & 1.31 & 1.29 & 1.11 & 1.65 \\
\hline$\left(\mathrm{K}_{2} \mathrm{O}+\mathrm{Na}_{2} \mathrm{O}\right) / \mathrm{CaO}$ & 10.33 & 5.11 & 12.24 & 13.09 & 18.32 & 30.96 & 8.03 & 11.46 & 15.78 & 51.33 & 9.93 & 18.47 & 126.38 & 16.47 \\
\hline MALI $^{\mathrm{d}}$ & 9.52 & 7.57 & 7.87 & 8.34 & 8.66 & 8.39 & 8.37 & 8.16 & 8.57 & 9.06 & 8.75 & 7.51 & 10.03 & 8.20 \\
\hline \multicolumn{15}{|c|}{ Trace elements (ppm) } \\
\hline $\mathrm{Rb}$ & 272 & 237 & 318 & 255 & 279 & 301 & 331 & 287 & 343 & 289 & 261 & 264 & 382 & 225 \\
\hline $\mathrm{Ba}$ & 427 & 585 & 257 & 414 & 367 & 48 & 907 & 414 & 409 & 240 & 600 & 373 & 13 & 221 \\
\hline Th & 22.6 & 18.2 & 23.1 & 24.5 & 22.7 & 36.8 & 19.5 & 27.9 & 31.8 & 22.0 & 20.7 & 26.8 & 32.5 & 30.5 \\
\hline $\mathrm{U}$ & 6.60 & 5.65 & 8.33 & 5.07 & 6.95 & 15.48 & 3.83 & 6.87 & 6.93 & 4.63 & 4.21 & 6.34 & 5.52 & 3.95 \\
\hline $\mathrm{Pb}$ & 11.9 & 7.5 & 18.1 & 13.6 & 12.9 & 16.0 & - & - & - & 12.9 & - & - & - & - \\
\hline $\mathrm{Nb}$ & 4.49 & 5.03 & 2.23 & 15.09 & 2.27 & 1.80 & 29.82 & 20.62 & 26.01 & 24.42 & 16.92 & 21.01 & 52.15 & 9.10 \\
\hline $\mathrm{Ta}$ & 0.56 & 0.54 & 0.12 & 0.38 & 0.36 & 0.38 & 3.50 & 2.38 & 1.67 & 2.01 & 0.82 & 1.35 & 2.34 & 0.61 \\
\hline $\mathrm{Ga}$ & 15.5 & 15.8 & 19.2 & 23.2 & 17.6 & 16.3 & 22.1 & 15.5 & 17.9 & 23.1 & 16.2 & 17.6 & 27.9 & 14.8 \\
\hline $\mathrm{Sr}$ & 63.1 & 163.9 & 42.9 & 52.3 & 37.5 & 11.0 & 166.6 & 87.7 & 112.2 & 29.9 & 83.6 & 55.4 & 0.5 & 65.2 \\
\hline $\mathrm{Hf}$ & 1.41 & 1.60 & 0.39 & 4.70 & 0.77 & 0.46 & 9.81 & 5.88 & 6.14 & 8.68 & 10.72 & 10.10 & 6.23 & 4.21 \\
\hline $\mathrm{Zr}$ & 247 & 209 & 137 & 191 & 233 & 140 & 347 & 136 & 160 & 205 & 287 & 233 & 131 & 96 \\
\hline $\mathrm{Y}$ & 44 & 54 & 97 & 68 & 66 & 63 & 37 & 52 & 20 & 43 & 33 & 75 & 19 & 35 \\
\hline $\mathrm{La}$ & 55 & 73 & 62 & 74 & 88 & - & - & 69 & 107 & 74 & 86 & 210 & - & 80 \\
\hline $\mathrm{Ce}$ & 81 & 101 & 73 & 145 & 109 & - & - & 116 & 133 & 86 & 180 & 269 & - & 106 \\
\hline $\mathrm{Nd}$ & 50 & 64 & 58 & 69 & 78 & - & - & 48 & 45 & 57 & 67 & 135 & - & 68 \\
\hline $\mathrm{Sm}$ & 9 & 12 & 12 & 14 & 16 & - & - & 10 & 6 & 10 & 12 & 21 & - & 12 \\
\hline $\mathrm{Eu}$ & 0.37 & 0.67 & 0.49 & 0.61 & 0.60 & - & - & 0.31 & 0.67 & 0.50 & 0.51 & 1.09 & - & 0.61 \\
\hline $\mathrm{Gd}$ & 8 & 11 & 14 & 11 & 15 & - & - & 9 & 5 & 7 & 8 & 20 & - & 8 \\
\hline Dy & 7.36 & 9.24 & 15.13 & 11.19 & 12.75 & - & - & 10.52 & 3.42 & 6.41 & 8.50 & 17.86 & - & 8.24 \\
\hline Ho & 1.32 & 1.78 & 3.19 & 2.19 & 2.37 & - & - & 2.07 & 0.51 & 1.13 & 1.40 & 2.90 & - & 1.26 \\
\hline $\mathrm{Er}$ & 4.82 & 6.28 & 10.86 & 6.58 & 7.02 & - & - & 7.29 & 1.88 & 3.79 & 5.11 & 8.53 & - & 4.34 \\
\hline $\mathrm{Yb}$ & 5.6 & 6.4 & 11.2 & 7.1 & 7.1 & - & - & 7.0 & 2.3 & 4.3 & 4.8 & 7.8 & - & 4.1 \\
\hline $\mathrm{Lu}$ & 0.31 & 0.32 & 2.09 & 0.84 & 0.45 & - & - & 0.58 & $<0.05$ & 0.68 & 0.35 & 0.67 & - & 0.18 \\
\hline$\Sigma \mathrm{REE}$ & 223 & 285 & 262 & 342 & 336 & - & - & 281 & 304 & 251 & 372 & 694 & - & 293 \\
\hline LREE/HREE & 7.15 & 7.27 & 3.73 & 7.87 & 6.49 & - & - & 6.76 & 22.90 & 10.10 & 12.17 & 11.11 & - & 10.09 \\
\hline$(\mathrm{La} / \mathrm{Sm})_{\mathrm{N}}$ & 3.68 & 3.96 & 3.33 & 3.27 & 3.60 & - & - & 4.28 & 11.86 & 4.56 & 4.69 & 6.35 & - & 4.25 \\
\hline$(\mathrm{Gd} / \mathrm{Yb})_{\mathrm{N}}$ & 1.19 & 1.34 & 1.04 & 1.29 & 1.76 & - & - & 1.06 & 1.61 & 1.29 & 1.41 & 2.08 & - & 1.65 \\
\hline$(\mathrm{La} / \mathrm{Yb})_{\mathrm{N}}$ & 6.62 & 7.68 & 3.73 & 7.05 & 8.41 & - & - & 6.68 & 31.49 & 11.59 & 12.05 & 18.24 & - & 13.11 \\
\hline $\mathrm{Eu}_{\mathrm{N}} / \mathrm{Eu}^{* \mathrm{e}}$ & 0.13 & 0.18 & 0.12 & 0.15 & 0.12 & - & - & 0.10 & 0.40 & 0.18 & 0.16 & 0.16 & - & 0.19 \\
\hline
\end{tabular}


Table 3. Continuation.

\begin{tabular}{|c|c|c|c|c|c|c|c|c|c|c|c|c|c|}
\hline \multirow{4}{*}{$\begin{array}{l}\text { Unit rock } \\
\text { Pluton name } \\
\text { Facies/Lithotype } \\
\text { Sample } \\
\end{array}$} & \multicolumn{10}{|c|}{ Maloquinha Intrusive Suite } & \multirow{2}{*}{\multicolumn{3}{|c|}{$\begin{array}{c}\text { PIS } \\
\text { Ig. Salustiano granite }\end{array}$}} \\
\hline & \multicolumn{6}{|c|}{ Serra Alta granite } & \multirow{2}{*}{\multicolumn{4}{|c|}{$\begin{array}{l}\text { Ig. Tabuleiro granite } \\
\text { Syenogranite }\end{array}$}} & & & \\
\hline & \multicolumn{3}{|c|}{ ASG } & \multicolumn{3}{|c|}{ AFG } & & & & & \multicolumn{2}{|c|}{ MzG } & \multirow{2}{*}{$\begin{array}{c}\text { QzMz } \\
\text { FH- } \\
17\end{array}$} \\
\hline & $\begin{array}{l}\text { CE- } \\
250\end{array}$ & $\begin{array}{l}\text { CE- } \\
237\end{array}$ & $\begin{array}{l}\text { CE- } \\
241\end{array}$ & $\begin{array}{l}\text { CE- } \\
242\end{array}$ & $\begin{array}{l}\text { CE- } \\
253\end{array}$ & $\begin{array}{l}\text { CE- } \\
239\end{array}$ & $\begin{array}{l}\text { EY- } \\
75 B\end{array}$ & $\begin{array}{l}\text { CE- } \\
304\end{array}$ & $\begin{array}{l}\text { EY- } \\
70 B\end{array}$ & \begin{tabular}{|l|} 
EY- \\
57B
\end{tabular} & $\begin{array}{l}\text { MV- } \\
116\end{array}$ & $\begin{array}{c}\text { FH- } \\
18\end{array}$ & \\
\hline \multicolumn{14}{|c|}{ Major elements (wt.\%) } \\
\hline $\mathrm{SiO}_{2}$ & 69.07 & 72.05 & 75.93 & 73.76 & 74.43 & 74.56 & 72.31 & 74.78 & 75.29 & 75.80 & 67.05 & 74.17 & 76.69 \\
\hline $\mathrm{TiO}_{2}$ & 0.35 & 0.23 & 0.21 & 0.22 & 0.27 & 0.1 & 0.21 & 0.09 & 0.09 & 0.22 & 0.31 & 0.24 & 0.23 \\
\hline $\mathrm{Al}_{2} \mathrm{O}_{3}$ & 16.83 & 13.91 & 13.97 & 13.29 & 14.46 & 11.93 & 12.90 & 12.67 & 12.52 & 13.47 & 15.65 & 12.76 & 12.83 \\
\hline $\mathrm{Fe}_{2} \mathrm{O}_{3}$ & 3.05 & 2.42 & 2.21 & 2.11 & 1.97 & 1.22 & 1.97 & 1.64 & 1.33 & 2.55 & 2.34 & 2.10 & 1.92 \\
\hline $\mathrm{MnO}$ & 0.08 & 0.05 & 0.06 & 0.03 & 0.04 & 0.02 & 0.06 & 0.03 & 0.02 & 0.07 & 0.04 & 0.03 & 0.03 \\
\hline $\mathrm{MgO}$ & 0.30 & 0.17 & 0.18 & 0.15 & 0.18 & 0.05 & 0.13 & 0.09 & 0.04 & 0.15 & 0.70 & 0.56 & 0.53 \\
\hline $\mathrm{CaO}$ & 0.96 & 0.51 & 0.60 & 0.53 & 0.37 & 0.15 & 0.55 & 0.56 & 0.30 & 0.59 & 2.36 & 1.95 & 1.73 \\
\hline $\mathrm{Na}_{2} \mathrm{O}$ & 4.85 & 4.32 & 3.68 & 4.04 & 3.87 & 3.30 & 3.80 & 3.68 & 3.56 & 3.94 & 4.04 & 3.86 & 3.82 \\
\hline $\mathrm{K}_{2} \mathrm{O}$ & 6.44 & 5.91 & 5.41 & 5.85 & 5.51 & 4.57 & 5.03 & 4.73 & 5.06 & 5.43 & 3.58 & 3.40 & 3.24 \\
\hline $\mathrm{P}_{2} \mathrm{O}_{5}$ & 0.06 & - & 0.04 & 0.04 & 0.04 & - & 0.01 & - & - & - & 0.09 & 0.05 & 0.06 \\
\hline LOI & 0.49 & 3.22 & 0.59 & 0.72 & 0.71 & 1.00 & 0.24 & 0.31 & 0.49 & 0.15 & 0.32 & 0.29 & 0.25 \\
\hline Total & 102.48 & 102.80 & 102.88 & 100.74 & 101.85 & 96.91 & 97.21 & 98.59 & 98.71 & 102.38 & 96.68 & 99.41 & 101.33 \\
\hline $\mathrm{A} / \mathrm{CNK}^{\mathrm{a}}$ & 1.01 & 0.96 & 1.07 & 0.95 & 1.11 & 1.12 & 1.02 & 1.04 & 1.05 & 1 & 1.04 & 0.94 & 0.99 \\
\hline $\mathrm{A} / \mathrm{NK}^{\mathrm{b}}$ & 1.13 & 1.03 & 1.17 & 1.02 & 1.17 & 1.15 & 1.10 & 1.13 & 1.10 & 1.09 & 1.45 & 1.27 & 1.31 \\
\hline Fe-index ${ }^{c}$ & 0.90 & 0.93 & 0.92 & 0.93 & 0.91 & 0.96 & 0.93 & 0.94 & 0.97 & 0.94 & 0.75 & 0.77 & 0.77 \\
\hline $\mathrm{K}_{2} \mathrm{O}+\mathrm{Na}_{2} \mathrm{O}$ & 11.29 & 10.23 & 9.09 & 9.89 & 9.38 & 7.87 & 8.83 & 8.41 & 8.62 & 9.37 & 7.82 & 7.26 & 7.06 \\
\hline $\mathrm{K}_{2} \mathrm{O} / \mathrm{Na}_{2} \mathrm{O}$ & 1.33 & 1.37 & 1.47 & 1.45 & 1.42 & 1.38 & 1.32 & 1.29 & 1.42 & 1.38 & 0.89 & 0.88 & 0.85 \\
\hline$\left(\mathrm{K}_{2} \mathrm{O}+\mathrm{Na}_{2} \mathrm{O}\right) / \mathrm{CaO}$ & 11.76 & 20.06 & 15.15 & 18.66 & 25.35 & 52.47 & 16.05 & 15.02 & 28.73 & 15.88 & 3.31 & 3.72 & 4.08 \\
\hline MALI $^{\mathrm{d}}$ & 10.33 & 9.72 & 8.49 & 9.36 & 9.01 & 7.72 & 8.28 & 7.85 & 8.32 & 8.78 & 5.26 & 5.31 & 5.33 \\
\hline \multicolumn{14}{|c|}{ Trace elements (ppm) } \\
\hline $\mathrm{Rb}$ & 261 & 331 & 372 & 358 & 262 & 457 & 235 & 336 & 290 & 248 & 165.6 & 209.8 & 248.8 \\
\hline $\mathrm{Ba}$ & 675 & 395 & 441 & 477 & 459 & 66 & 571 & 62 & 89 & 540 & 1475 & 1345 & 1501 \\
\hline Th & 18.9 & 23.2 & 28.7 & 25.7 & 21.8 & 29.9 & 14.9 & 25.5 & 19.1 & 32.7 & 12.3 & 11.6 & 14.5 \\
\hline $\mathrm{U}$ & 3.94 & 7.10 & 7.86 & 5.59 & 4.59 & 6.10 & 4.18 & 13.23 & 7.99 & 9.98 & 1.36 & 1.81 & 1.98 \\
\hline $\mathrm{Pb}$ & - & - & - & - & - & - & 13 & 16.9 & 11.5 & 19.1 & - & - & - \\
\hline $\mathrm{Nb}$ & 15.83 & 20.74 & 21.28 & 16.89 & 22.85 & 23.75 & 13.59 & 17.47 & 17.42 & 2.11 & 5.15 & 8.04 & 6.53 \\
\hline $\mathrm{Ta}$ & 0.65 & 1.92 & 1.81 & 1.11 & 1.30 & 2.12 & $<0,05$ & 22.81 & $<0,05$ & 0.35 & $<0,05$ & 0.94 & 0.75 \\
\hline $\mathrm{Ga}$ & 16.3 & 16.5 & 16.7 & 16 & 16.8 & 17.9 & 17.6 & 18.7 & 18.5 & 16 & 16.5 & 15.7 & 16.2 \\
\hline $\mathrm{Sr}$ & 104.8 & 62.7 & 76.2 & 81.2 & 64 & 17.3 & 43.5 & 18.7 & 19.1 & 45.3 & 702.4 & 660.4 & 675.1 \\
\hline $\mathrm{Hf}$ & 9.95 & 7.76 & 8.09 & 7.46 & 9.11 & 7.65 & 6.51 & 2.18 & 5.65 & 0.86 & 3.77 & 3.94 & 5.17 \\
\hline $\mathrm{Zr}$ & 341 & 216 & 205 & 233 & 282 & 138 & 271 & 142 & 158 & 298 & 115 & 110 & 152 \\
\hline $\mathrm{Y}$ & 40 & 47 & 48 & 43 & 175 & 48 & 50 & 89 & 68 & 56 & 8 & 8 & 14 \\
\hline $\mathrm{La}$ & 95 & 107 & 115 & 98 & - & 56 & 74 & 59 & 59 & 84 & 36 & 40 & 62 \\
\hline $\mathrm{Ce}$ & 178 & 182 & 176 & 147 & - & 93 & 100 & 64 & 72 & 134 & 63 & 67 & 113 \\
\hline $\mathrm{Nd}$ & 77 & 70 & 84 & 67 & - & 41 & 56 & 54 & 43 & 73 & 25 & 25 & 47 \\
\hline $\mathrm{Sm}$ & 12 & 10 & 14 & 11 & - & 8 & 11 & 11 & 9 & 13 & 4 & 4 & 7 \\
\hline $\mathrm{Eu}$ & 0.49 & 0.33 & 0.32 & 0.28 & - & $<0,05$ & 0.99 & 0.20 & 0.26 & 0.74 & 0.10 & $<0,05$ & 0.43 \\
\hline $\mathrm{Gd}$ & 11 & 8 & 10 & 9 & - & 7 & 9 & 11 & 8 & 12 & 2 & 2 & 4 \\
\hline Dy & 11.15 & 8.58 & 11.48 & 9.07 & - & 8.60 & 8.12 & 12.44 & 8.39 & 10.36 & 1.34 & 1.36 & 2.57 \\
\hline Ho & 1.78 & 1.54 & 1.90 & 1.54 & - & 1.75 & 1.61 & 2.63 & 1.56 & 1.79 & 0.06 & 0.13 & 0.32 \\
\hline $\mathrm{Er}$ & 5.95 & 4.85 & 6.02 & 5.03 & - & 6.31 & 4.97 & 8.72 & 5.46 & 5.82 & 0.78 & 0.79 & 1.30 \\
\hline $\mathrm{Yb}$ & 5.7 & 5.7 & 6.5 & 5.6 & - & 7.7 & 4.9 & 10.5 & 6.5 & 6.5 & 0.7 & 0.8 & 1.3 \\
\hline $\mathrm{Lu}$ & 0.41 & 0.43 & 0.43 & 0.46 & - & 0.68 & 0.69 & 1.49 & 1.04 & 0.42 & $<0,05$ & $<0,05$ & $<0,05$ \\
\hline ¿REE & 399 & 400 & 425 & 353 & - & 230 & 272 & 235 & 215 & 342 & 133 & 141 & 239 \\
\hline LREE/HREE & 10.09 & 12.78 & 10.85 & 10.80 & - & 6.28 & 8.32 & 4.14 & 6.13 & 8.40 & 25.54 & 25.22 & 23.10 \\
\hline$(\mathrm{La} / \mathrm{Sm})_{\mathrm{N}}$ & 5 & 6.64 & 5.20 & 5.55 & - & 4.56 & 4.22 & 3.38 & 4.04 & 4.12 & 6.38 & 7.23 & 5.47 \\
\hline$(\mathrm{Gd} / \mathrm{Yb})_{\mathrm{N}}$ & 1.60 & 1.17 & 1.23 & 1.25 & - & 0.75 & 1.55 & 0.85 & 1 & 1.47 & 2.45 & 2.33 & 2.74 \\
\hline$(\mathrm{La} / \mathrm{Yb})_{\mathrm{N}}$ & 11.28 & 12.73 & 11.92 & 11.79 & - & 4.94 & 10.24 & 3.79 & 6.13 & 8.77 & 35.16 & 33.90 & 31.99 \\
\hline $\mathrm{Eu}_{\mathrm{N}} / \mathrm{Eu}^{* \mathrm{e}}$ & 0.13 & 0.11 & 0.08 & 0.09 & - & 0.02 & 0.30 & 0.06 & 0.09 & 0.18 & 0.11 & 0.05 & 0.24 \\
\hline
\end{tabular}

Facies/Lithotype: BAMzG - biotite-amphibole monzogranite, BASG - biotite-amphibole syenogranite, BAFG - biotite alkali feldspar granite, MzG monzogranite, QzMz - quartz monzonite.

${ }^{\mathrm{a}} \mathrm{A} / \mathrm{CNK}=$ molecular $\mathrm{Al}_{2} \mathrm{O}_{3} /\left(\mathrm{CaO}+\mathrm{Na}_{2} \mathrm{O}+\mathrm{K}_{2} \mathrm{O}\right),{ }^{\mathrm{b}} \mathrm{A} / \mathrm{NK}=$ molecular $\mathrm{Al}_{2} \mathrm{O}_{3} /\left(\mathrm{Na}_{2} \mathrm{O}+\mathrm{K}_{2} \mathrm{O}\right),{ }^{\mathrm{c}} \mathrm{Fe}-$ index $=\mathrm{FeO}_{\mathrm{t}} /\left(\mathrm{FeO}_{\mathrm{t}}+\mathrm{MgO}\right),{ }^{\mathrm{d}} \mathrm{MALI}=\left(\mathrm{Na} \mathrm{O}_{2}+\mathrm{K}_{2} \mathrm{O}-\mathrm{CaO}\right),{ }^{\mathrm{e}} \mathrm{Eu} \mathrm{N} / \mathrm{Eu}^{*}=\mathrm{Eu} \mathrm{N}_{\mathrm{N}} /$ $\left(\mathrm{Sm}_{\mathrm{N}} \times \mathrm{Gd}_{\mathrm{N}}\right)^{1 / 2}$. "N" represents chondrite normalized value (Eversen et al. 1978). "-" not detected or not determined values. 

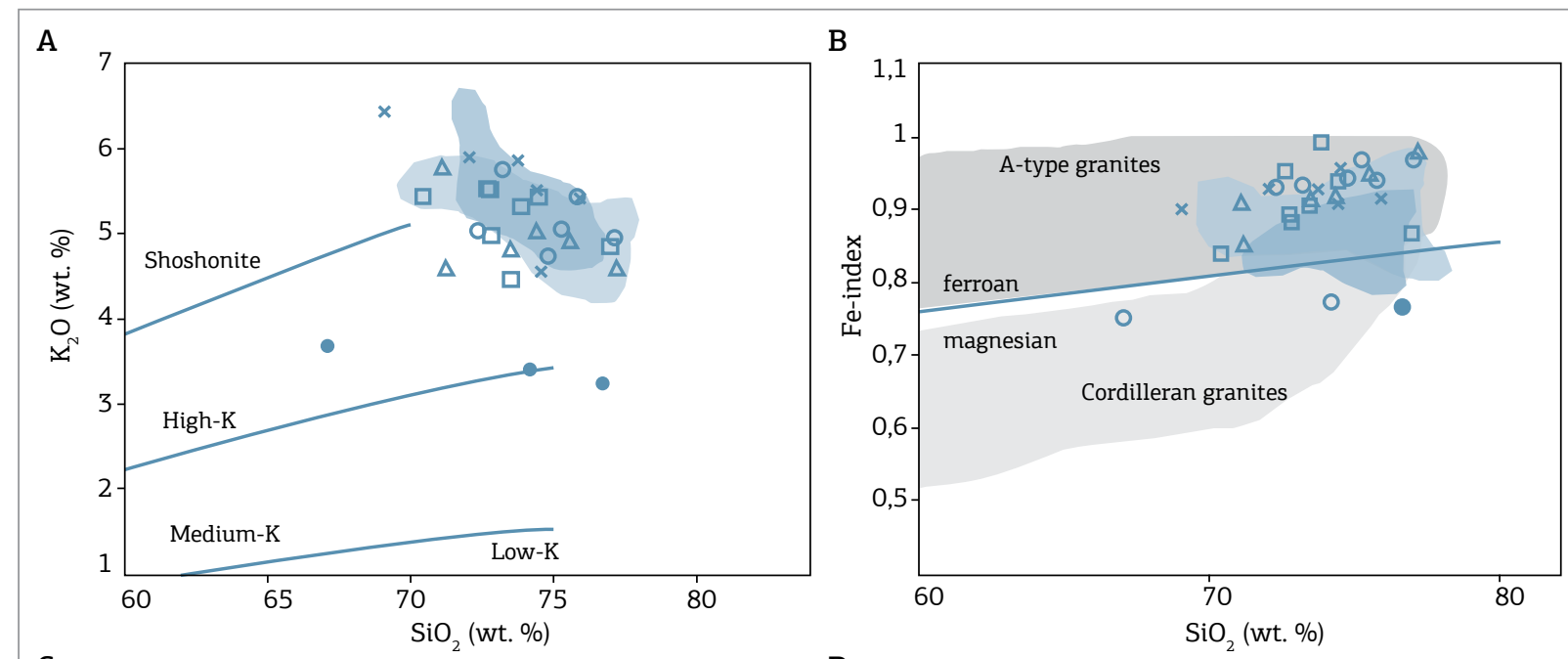

C

D
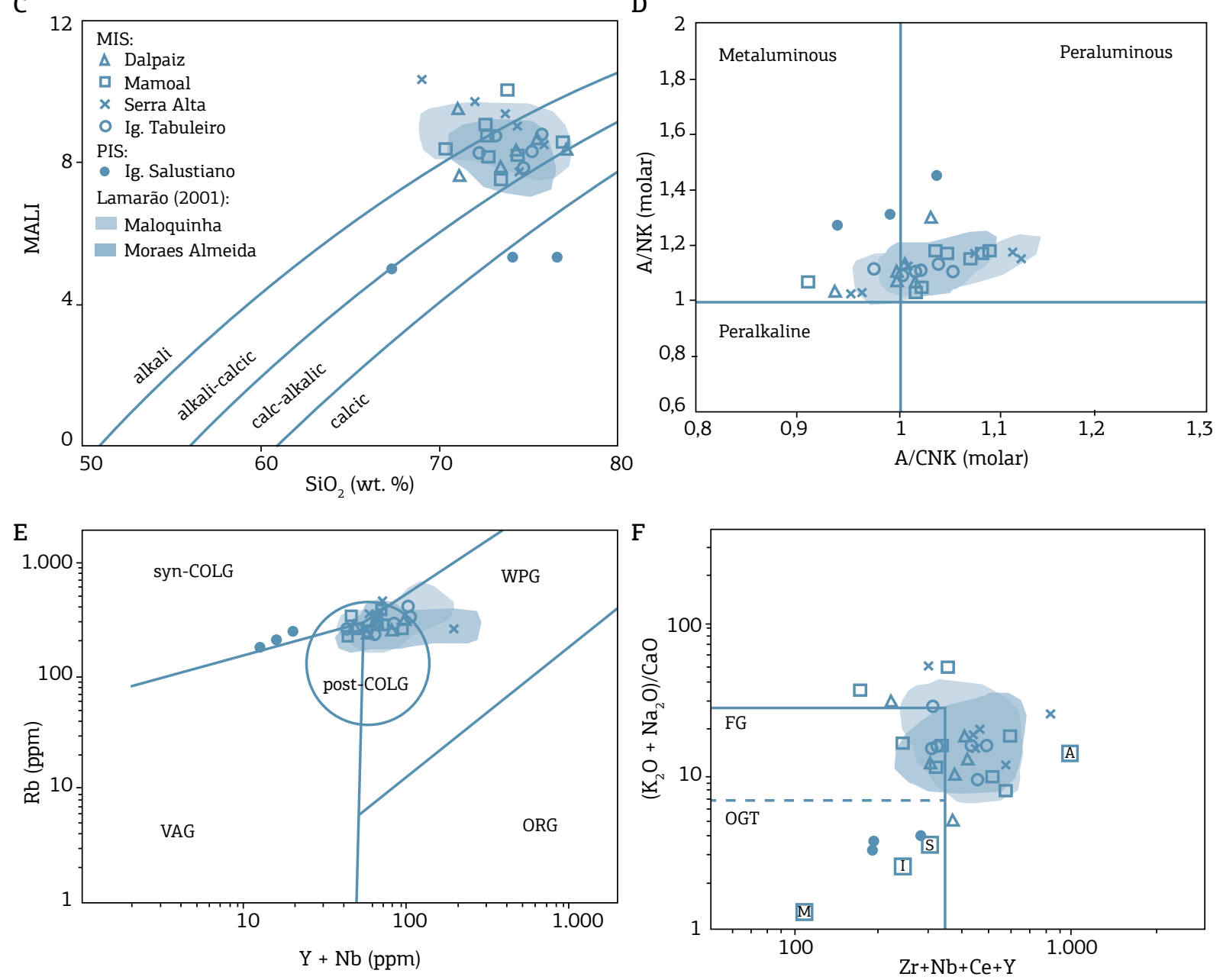

Figure 5. Geochemical diagrams for study rocks from the MIS and PIS, including fields related to MIS from Lamarão et al. (2002): (A) $\mathrm{K}_{2} \mathrm{O}$ vs. $\mathrm{SiO}_{2}$; (B) $\mathrm{Fe}$-index $\left[\mathrm{FeO}_{\mathrm{t}} /\left(\mathrm{FeO}_{\mathrm{t}}+\mathrm{MgO}\right)\right]$ vs. $\mathrm{SiO}_{2}$ from Frost et al. (2001) $(\mathrm{FeO}$ calculated as $\mathrm{FeO}) ;(\mathrm{C}) \mathrm{MALI}\left(\mathrm{Na}_{2} \mathrm{O}+\mathrm{K}_{2} \mathrm{O}-\mathrm{CaO}\right)$ vs. $\mathrm{SiO}_{2}$; (D) A/NK $\left(\mathrm{Al}_{2} \mathrm{O}_{3} / \mathrm{Na}_{2} \mathrm{O}+\mathrm{K}_{2} \mathrm{O}\right)$ vs. A/CNK $\left(\mathrm{Al}_{2} \mathrm{O}_{3} / \mathrm{CaO}+\mathrm{Na}_{2} \mathrm{O}+\mathrm{K}_{2} \mathrm{O}\right)$ molar from Shand (1951); (E) Rb vs. Y + Nb, fields from Pearce (1996): Syn-COLG - syn-collsional granites, WPG - withinplate granites, post-COLG - post-collisional granites, VAG - volcanic arc granites, ORG - ocean ridge granites; (F) $\left(\mathrm{K}_{2} \mathrm{O}+\mathrm{Na}_{2} \mathrm{O}\right) / \mathrm{CaO}$ vs. $(\mathrm{Zr}+\mathrm{Nb}+\mathrm{Ce}+\mathrm{Y})$ diagram, average composition of A-type (A), M-type (M), S-type (S), I-type (I) granites and the fields for fractionated felsic granites (FG) and unfractionated M-, I- and S-type granites (OGT) according to Whallen et al. (1987). 
of the REE $\left[(\mathrm{La} / \mathrm{Yb})_{\mathrm{N}}\right]$ between 32 and 35.2. The MIS and PIS LREE/HREE ratios are 3.6 to 12.6 and 23 to 25.3 respectively. Both units show sharp Eu negative anomaly, MIS $\left(\mathrm{Eu}_{\mathrm{N}} / \mathrm{Eu}^{*}\right)=0.02-0.4$ and PIS $\left(\mathrm{Eu}_{\mathrm{N}} / \mathrm{Eu}^{*}\right)=0.1-0.2$.

\section{Sm-Nd WHOLE ROCK}

\section{Analytical procedures}

Selected samples for $\mathrm{Sm}-\mathrm{Nd}$ analyses were powdered with aid of a Shatter Box type rings mill and agate mortar and pestle. For each sample, approximately $100 \mathrm{mg}$ was used in this procedure. The chemical digestion of the samples and the chemical extraction of the Sm and Nd elements followed the procedures described by Oliveira et al. (2008). In the first step, sample dissolution was carried out in concentrated $\mathrm{HNO}_{3}{ }^{* *}$ (bi-distilled) and $\mathrm{HF}^{* *}$. The second step was conducted using $\mathrm{HCl}^{* *} 6 \mathrm{~N}$ and $2 \mathrm{~N}$ with heated for evaporation. The sample solid residue was dissolved again (in $\mathrm{HCl}^{* *} 2 \mathrm{~N}$ ) to be introduced into the ion-exchange columns. REE extraction was in Teflon columns filled with BioRad Dowex $50 \mathrm{~W}-\mathrm{X} 8$ cationic resin by a sequence of $\mathrm{HCl}^{* *} 2 \mathrm{~N}$ and $\mathrm{HNO}_{3}{ }^{* *} 3 \mathrm{~N}$. Sm and $\mathrm{Nd}$ elements were separated from the other REE by ion exchange chromatography in Teflon columns filled with Dowex AG1-X4 anionic resin by a sequence of $\mathrm{HCl}^{* *} 0.2 \mathrm{~N}$ and $\mathrm{HCl}^{* *} 0.3 \mathrm{~N}$.

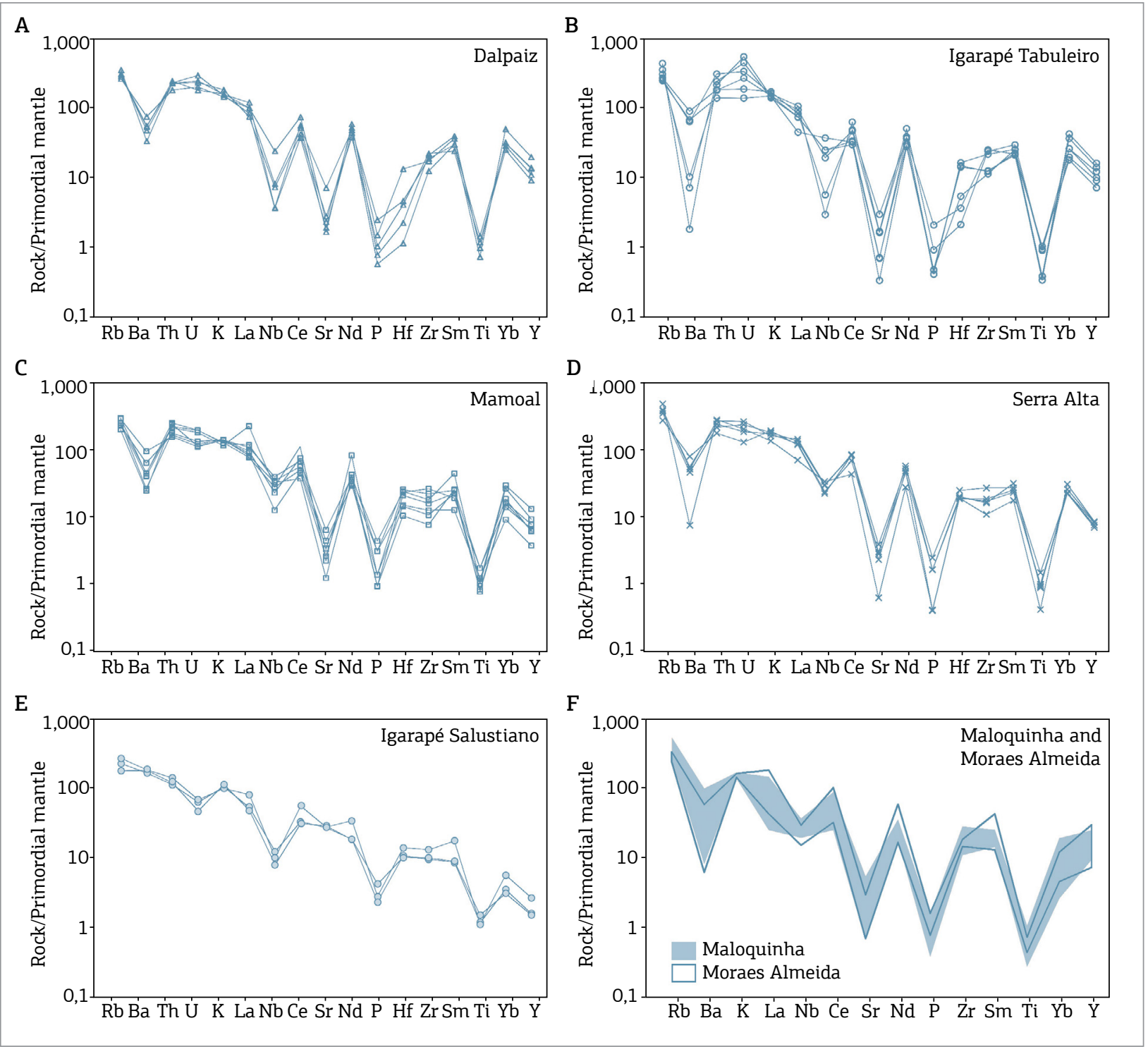

Figure 6. Normalized spidergram to primordial mantle (Wood 1979) for the MIS rocks: (A) Dalpaiz granite; (B) Igarapé Tabuleiro granite; (C) Mamoal granite; (D) Serra Alta granite, PIS; (E) Igarapé Salustiano granite; (F) MIS related units: Maloquinha granite and Moraes Almeida Formation from Lamarão et al. (2002). 
Isotopic analyses were performed in ICP-MS Neptune model from Thermo Finnigan, equipped with 9 Faraday cups, an electron multiplier and five ion-counters multi ion channel (MIC) type of Isotope Geology Laboratory of the Federal University of Pará (Pará-Iso). The Nd element mass fractionation was normalized to ${ }^{146} \mathrm{Nd} /{ }^{144} \mathrm{Nd}=$ 0,7219 ratio. During analyses, ${ }^{143} \mathrm{Nd} /{ }^{144} \mathrm{Nd}$ average ratios of 0.5118339 and 0.5126335 were obtained respectively for La Jolla and Basalt, Columbia River (BCR$01)$ standards. $\mathrm{Nd}(28.58 \mathrm{ppm})$ and $\mathrm{Sm}$ (6.56 ppm) concentrations for La Jolla standard were also obtained. Total measured blanks were $<0.6 \mathrm{ng}$ for $\mathrm{Nd}$ and $<0.2 \mathrm{ng}$ for $\mathrm{Sm}$.

\section{Results}

Altogether, eight samples for Sm-Nd whole rock analyses were selected. Seven MIS and one PIS samples were analyzed, two biotite monzogranite samples (EY-23 and EY-26) from Dalpaiz granite, three syenogranite samples $(\mathrm{FH}-10, \mathrm{JK}-39$ and JK-40) from Mamoal granite, a syenogranite (CE-250) and a biotite quartz syenite samples (CE-252) from Serra Alta granite, and a biotite monzogranite (FH-18) from Igarapé Salustiano granite. The isotopic results are shown in Table 4. To calculate the $\varepsilon_{\mathrm{Nd}(\mathrm{t})}$ parameter, it was used the crystallization ages obtained in zircon $\mathrm{Pb}$-evaporation by Lamarão et al. (2002) for Maloquinha and Younger São Jorge granites, referring respectively to MIS and Igarapé Salustiano granite samples.

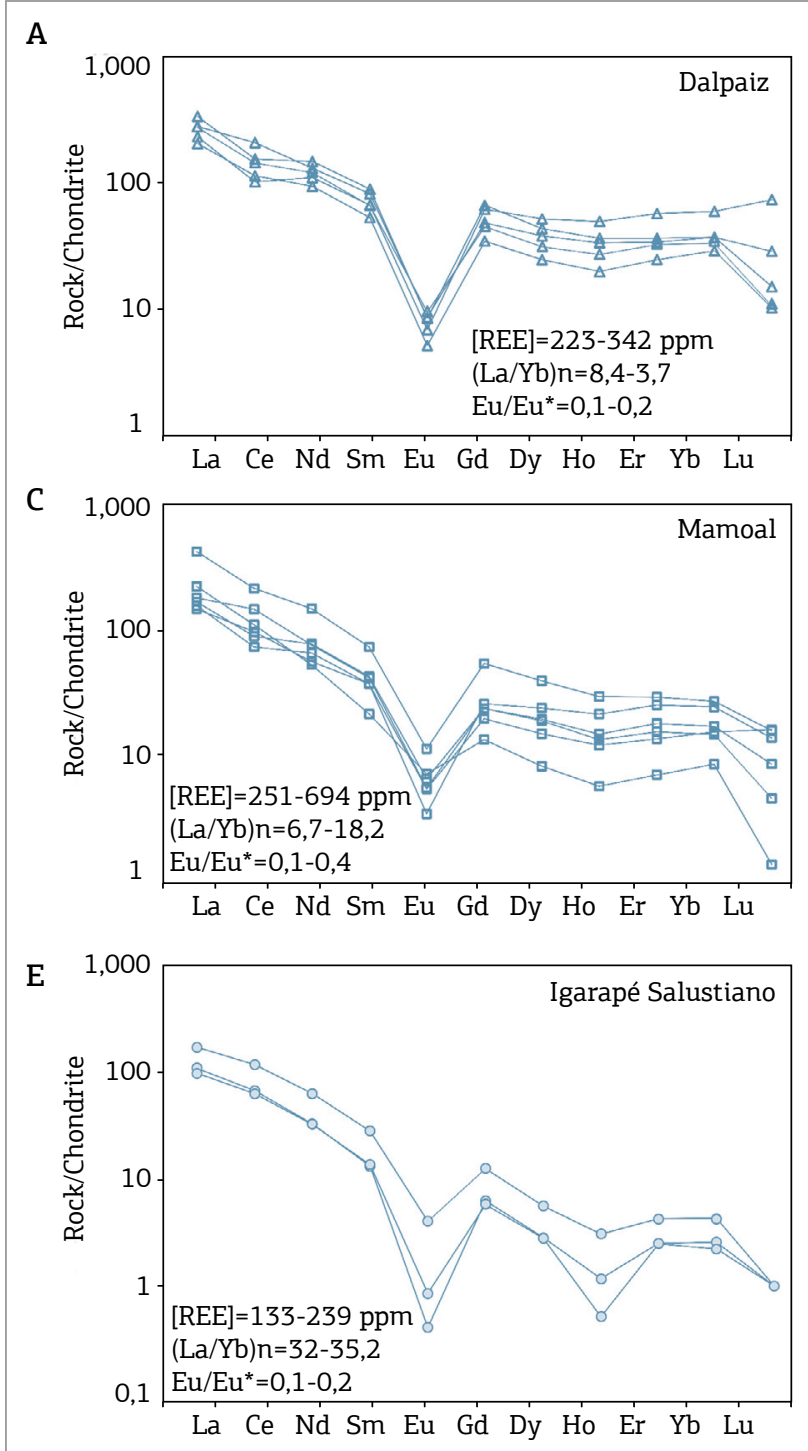

B
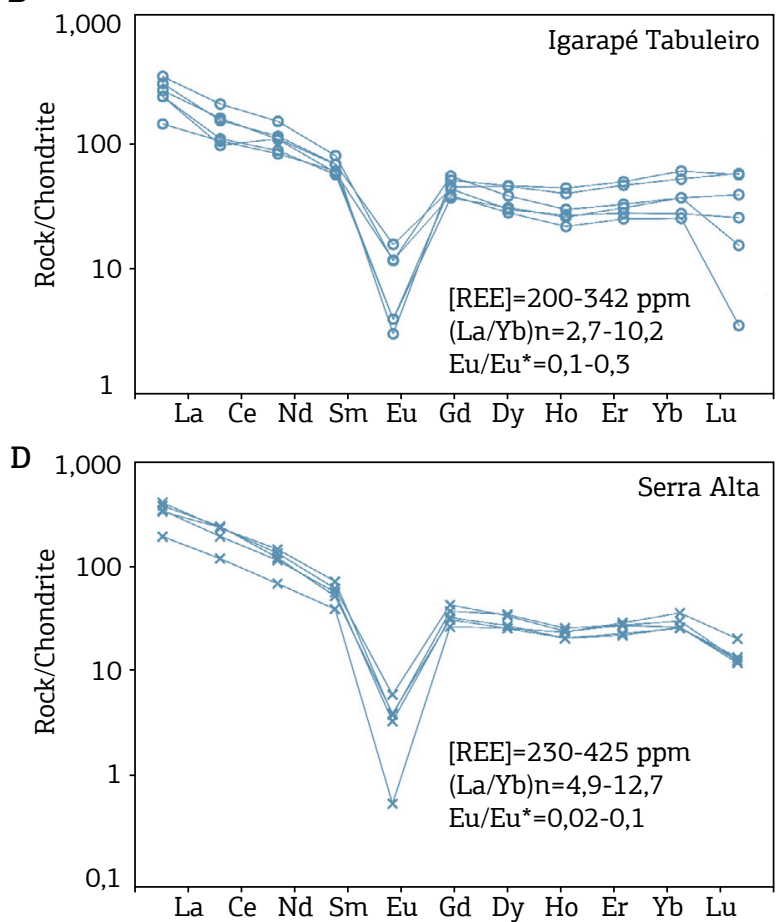

$\mathrm{F}$

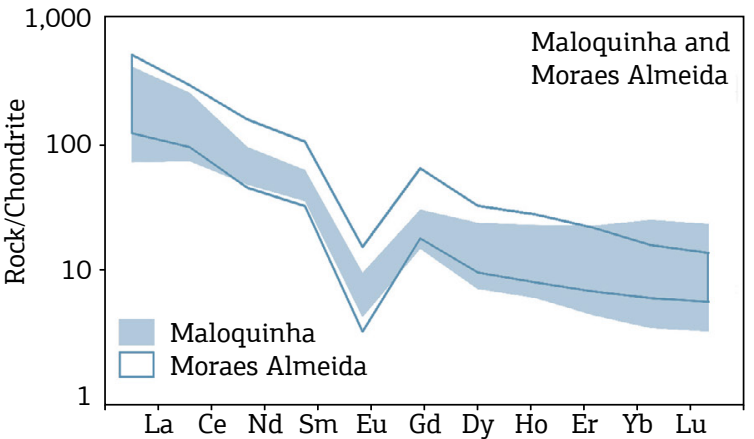

Figure 7. Normalized REE diagram to chondrite (Eversen et al. 1978) for the MIS samples: Dalpaiz granite (A), Igarapé Tabuleiro granite (B), Mamoal granite (C), Serra Alta granite (D), and PIS: Igarapé Salustiano granite (E), and the MIS related units: Maloquinha granite and Moraes Almeida Formation (F) from Lamarão et al. (2002). 
The $\mathrm{Sm}$ and $\mathrm{Nd}$ contents of the MIS samples were between 4 and 28 ppm for Sm, and 20 and 158 for $\mathrm{Nd}$, and Serra Alta granite shows concentrations much higher than other examined plutons in this suite. PIS sample content is 1 ppm for Sm and 10 ppm for $\mathrm{Nd}$. Except sample FH-18, all presented ${ }^{147} \mathrm{Sm} /{ }^{144} \mathrm{Nd}$ ratios within the $0.090-0.125$ range. However, the sample FH-18 shows $0.081{ }^{147} \mathrm{Sm} /{ }^{144} \mathrm{Nd}$ ratios (very close to cited range), besides its $\mathrm{T}_{\mathrm{DM}}$ age $(2.26 \mathrm{Ga})$ and $\varepsilon_{\mathrm{Nd}}(-2.26)$ parameter do not differ much from obtained values by Lamarão et al. (2005) for Younger São Jorge granite, here considered correlated to Igarapé Salustiano pluton. The $f_{(\mathrm{Sm} / \mathrm{Nd})}$ values were between -0.59 and -0.37 , suggesting that there was not meaningful $\mathrm{Sm} / \mathrm{Nd}$ fractionation during the formation of the analyzed set samples.

MIS samples present negative $\varepsilon_{\mathrm{Nd}(\mathrm{t})}$ values, between -5.01 and -0.76, and a wide field of $\mathrm{T}_{\mathrm{DM}}$ ages, dominantly paleoproterozoic $(2.46$ to $2.20 \mathrm{Ga})$ and an archean one $(2.60$ $\mathrm{Ga}$, sample JK-39). The results are indicative that MIS and PIS rocks were formed probably by interaction of paleoproterozoic magmas (juveniles) and resulting melting from crustal reworking of an Archean component. The mixing of a bulk of magma derived from mantle (paleoproterozoic) and a bulk derived from crust (Archean) ascribes to $\mathrm{T}_{\mathrm{DM}}$ ages only an estimate of crustal residence time (Arndt \& Goldstein 1987).

Fig. 8 shows the $\mathrm{Nd}\left(\varepsilon_{\mathrm{Nd}}\right)$ isotopic evolution diagram during geological time $(\mathrm{T})$, according to the ${ }^{147} \mathrm{Sm} /{ }^{144} \mathrm{Nd}$ ratio.
In this diagram, the studied samples in this work are plotted and compared to fields showing the obtained values by Lamarão et al. (2005) for Maloquinha granite plus Moraes Almeida volcanic rocks and Younger Sáo Jorge granite. This diagram also includes the mantle (CHUR) and the depleted mantle (DM) evolution curves proposed respectively by DePaolo \& Wasserburger (1976) and DePaolo (1981).

\section{DISCUSSION}

\section{Magmatic series and granitoid typology}

Granitoid typology is a widely applied approach since the 1980's (e.g., Pitcher 1983; Whalen et al. 1987; Chappell \& White 1992; Eby, 1992; Barbarin 1999). The defining characteristics of the I-, S- and M-type granites are mainly controlled by their magma source characteristics, whereas A-type granite can be affected by its unique emplacement environment and chemical characteristics. Loiselle \& Wones (1979) introduced the A-type granite terminology to designate anorogenic granite of alkaline nature and supposedly anhydrous. Geochemically, they have elevated values of $\mathrm{SiO}_{2}(>70 \%), \mathrm{FeO}_{\mathrm{t}} / \mathrm{MgO}, \mathrm{K}_{2} \mathrm{O} /$ $\mathrm{Na}_{2} \mathrm{O}, \mathrm{Ga} / \mathrm{Al}, \mathrm{Zr}, \mathrm{Nb}, \mathrm{Y}$, Ta and REE (except Eu), and low of $\mathrm{CaO}, \mathrm{Al}_{2} \mathrm{O}_{3}, \mathrm{MgO}, \mathrm{Ba}, \mathrm{Sr}$ and $\mathrm{Ti}$ (Whalen et al. 1987; Eby 1992). MIS samples are transitional between I-type fractionated granites and A-type granites (Fig. 5F). However, its high

Table 4. Sm-Nd whole rock isotopic data for the studied plutonic rocks.

\begin{tabular}{|c|c|c|c|c|c|c|c|c|c|c|c|c|}
\hline Sample & Lat. & Long. & $\begin{array}{c}\mathrm{Sm} \\
(\mathrm{ppm})\end{array}$ & $\begin{array}{c}\text { Nd } \\
(\text { ppm) }\end{array}$ & ${ }^{147} \mathrm{Sm} /$ & $\begin{array}{l}{ }^{143} \mathrm{Nd} / \\
{ }^{144} \mathrm{Nd}\end{array}$ & $\begin{array}{c}2 \sigma \\
\left(10^{-6}\right)\end{array}$ & $f_{(\mathrm{Sm} / \mathrm{Nd})}$ & $\varepsilon_{\mathrm{Nd}(0)}$ & $\begin{array}{c}\text { Zircon } \\
\text { age (Ma) }\end{array}$ & $\varepsilon_{\mathrm{Nd}(\mathrm{t})}$ & $\begin{array}{l}T_{\mathrm{DM}} \\
(\mathrm{Ga})\end{array}$ \\
\hline \multicolumn{13}{|c|}{ Dalpaiz granite (MIS) } \\
\hline EY-23 & -6.04199 & -55.77737 & 8.28 & 47.05 & 0.106391 & 0.511482 & 5 & -0.4591 & -22.55 & $1880^{1}$ & -0.76 & 2.22 \\
\hline EY-26 & -6.04923 & -55.70790 & 7.35 & 35.84 & 0.123905 & 0.511632 & 12 & -0.3701 & -19.62 & $1880^{1}$ & -2.07 & 2.41 \\
\hline \multicolumn{13}{|c|}{ Mamoal granite (MIS) } \\
\hline FH-10 & -6.15499 & -55.95954 & 3.84 & 19.56 & 0.118696 & 0.511574 & 10 & -0.3966 & -20.76 & $1880^{1}$ & -1.94 & 2.37 \\
\hline JK-39 & -6.20465 & -55.91682 & 6.98 & 36.68 & 0.115106 & 0.511373 & 10 & -0.4148 & -24.68 & $1880^{1}$ & -5.01 & 2.6 \\
\hline $\mathrm{JK}-40$ & -6.16689 & -55.92991 & 5.99 & 38.28 & 0.094646 & 0.511330 & 6 & -0.5188 & -25.52 & $1880^{1}$ & -0.89 & 2.2 \\
\hline \multicolumn{13}{|c|}{ Serra Alta granite (MIS) } \\
\hline CE-250 & -6.10300 & -56.19628 & 13.56 & 75.98 & 0.107935 & 0.511346 & 9 & -0.4513 & -25.2 & $1880^{1}$ & -3.8 & 2.46 \\
\hline CE-252 & -6.08756 & -56.21936 & 28.20 & 158.25 & 0.107748 & 0.511341 & 5 & -0.4522 & -25.3 & $1880^{1}$ & -3.85 & 2.46 \\
\hline \multicolumn{13}{|c|}{ Igarapé Salustiano granite (PIS) } \\
\hline FH-18 & -6.00688 & -56.05358 & 1.37 & 10.21 & 0.081017 & 0.511084 & 9 & -0.5881 & -30.31 & $1891^{2}$ & -2.26 & 2.26 \\
\hline
\end{tabular}

$\mathrm{T}_{\mathrm{DM}}$ and $\varepsilon_{\mathrm{Nd(t)}}$ were calculated relative to CHUR and depleted mantle (DM) with presente-day values of ${ }^{143} \mathrm{Nd} /{ }^{144} \mathrm{Nd}=0.512638$ and ${ }^{147} \mathrm{Sm} /{ }^{144} \mathrm{Nd}=0.1967$, following DePaolo (1981) model for Nd isotopic evolution of depleted mantle.

Data from Lamarão et al. (2002): ${ }^{1}$ Maloquinha granite, ${ }^{2}$ Younger São Jorge granite. 
Fe-index (>0.80), post-collisional granitic affinity, alkalic-calcic to alkalic character and high REE content with negative Eu anomalies, besides the marked correlation observed in the spidergrams (Fig. 6) of these rocks with Maloquinha granite and Moraes Almeida Formation (Lamarão et al. 2002), led us to classify them as A-type granites and group these rocks with the Maloquinha Intrusive Suite. Igarapé Salustiano granite samples plotted in the I- and S-type granites field of Whallen et al. (1987) diagram (Fig. 5F), but its metaluminous to peraluminous affinity and syn-collisional character suggest I-type granite affinity.

Since Loiselle \& Wones (1979), several models have been proposed to explain A-type granites petrogenesis (Collins et al. 1982; Anderson 1983; Whalen et al. 1987; Eby, 1992; Barbarin 1996; Patińo Douce 1997). In this work, A-type granitic classification proposed by Eby (1992), which uses the subdivision of A1 granitoids group, characterized by elemental ratios similar to those observed in oceanic island basalts (OIB), and A2 granitoids group, characterized by ratios ranging from those observed in continental crust to island arc basalts. The $\mathrm{A} 1$ group represents mantle differentiates from the same type of source that produces OIB, but formed during continental rifting or within-plate magmatism, and may also be formed as result of hot spot or mantle plume. The A2 group represents melts arising by underplating or collision of continent-continent/ocean-continent in continental crust. They are generated in post-collisional or post-orogenic environments with significant lithospheric anatexis contribution. MIS rocks plotted in the A2 granites field (Fig. 9). The deductions revealed from Eby diagrams could be confirmed both by other geochemical and isotopic parameters. The MIS shows negative $\mathrm{Ba}, \mathrm{Sr}$ and $\mathrm{Eu}$

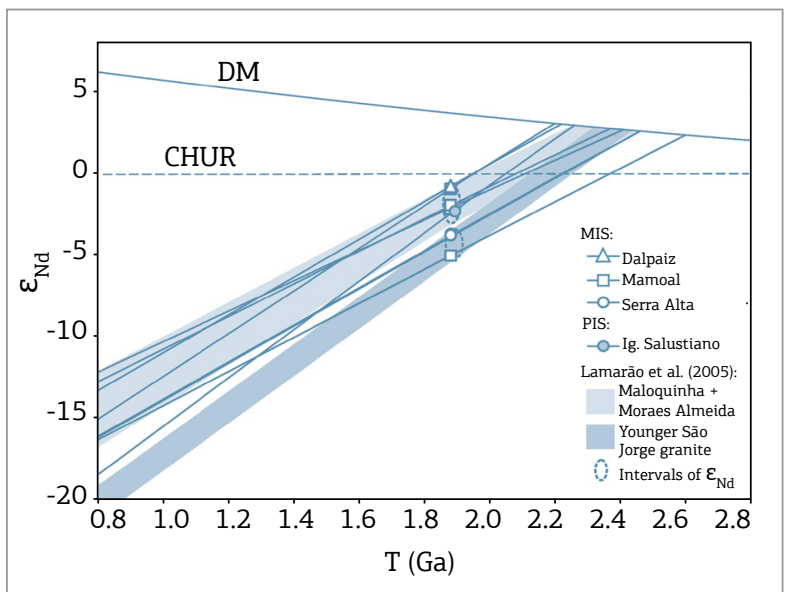

Figure 8. $\varepsilon_{\mathrm{Nd}}$ vs. time (T) showing $\mathrm{Nd}$ isotopic composition of the studied plutonic rocks. CHUR is undifferentiated Earth (DePaolo \& Wasserburger 1976) and DM depleted mantle (DePaolo 1981). anomalies, with the latter two the strongest (Figs. 6 and 7). Such anomalies, when taken together, are not produced by fractional crystallization, but by stability of plagioclase in the source region, furthering the increase of $\mathrm{K}_{2} \mathrm{O} / \mathrm{Na}_{2} \mathrm{O}$ ratio by retention of $\mathrm{Na}_{2} \mathrm{O}$, and it also decreases the $\mathrm{CaO}$ content (Patińo Douce 1997). Another geochemical characteristic that point in the same direction is the alkalic-calcic to alkalic nature and affinity of these rocks with post-collisional and within-plate granites (Fig. 5E). Such signatures may indicate a calc-alkaline to alkaline transition series, in an orogenic to post-orogenic tectonic environment (Bonin 1990; Barbarin 1999) or increase in arc maturity (Brown et al. 1984). The $\varepsilon_{\mathrm{Nd}(\mathrm{t})}$ isotopic parameters are negatives for MIS rocks (-0.76 to -2.26$)$, showing that these rocks were generated by anatexis of older crust (crustal reworking). It also enhances their affinity with Eby A2-type granites.

Igarapé Salustiano granite shows calc-alkaline signature of syn-collisional I-type granites and meta to peraluminous nature. It is medium to high-K and its Fe-index is $<0.80$, which display a close relationship to the Younger São Jorge granite (Lamarão et al. 2002), and inserted it in the PIS.

\section{Source of magmas and implications for geotectonic subdivision}

Investigation of the source rocks in the boundaries between the Amazonian Craton geochronological provinces is critical to understand their evolution. Thus, Sm-Nd data has been

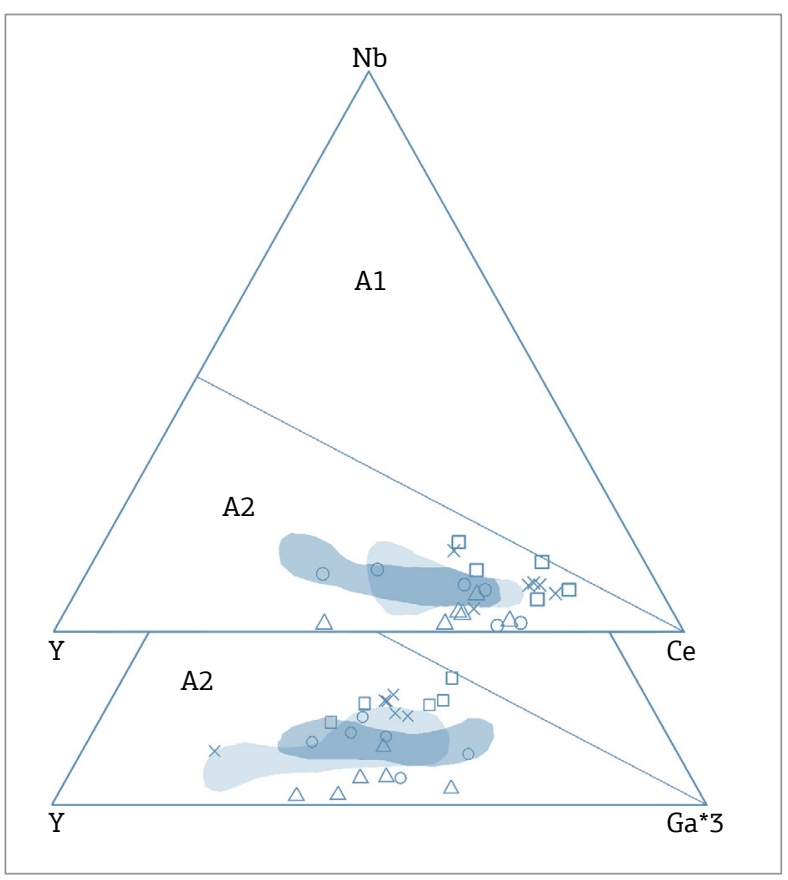

Figure 9. Nb-Y-Ce and Nb-Y-Ga*3 discriminant diagrams for A1- and A2-type granitoids (Eby 1992) for the MIS rocks. Symbols as Fig. 5. 
used to obtain information about the sources of these rocks and to outline boundaries among these provinces. The Central Amazonian Province represented by archean crustal source rock contrasts with the Tapajós-Parima Province, represented by juvenile paleoproterozoic source rocks or with the low participation of older crust. This contrast was established by Tassinari (1996), who called this province Ventuari-Tapajós. Santos (2003) and Tassinari \& Macambira (2004) adopted the same criteria for subdivision of Central Amazonian and Tapajós-Parima (Santos 2003) or Ventuari-Tapajós (Tassinari and Macambira 2004) provinces.

In the southern portion of the Amazonian Craton, the boundary between these two provinces is poorly defined. Santos (2003), Tassinari \& Macambira (2004), and Vasquez et al. (2008a) disagreed on the boundary between them. This divergence owes to the absence of tectonic structures that could help to outline this boundary. Such structures have not been identified yet in a satisfactory way for a tectonic subdivision, and geological structures observed on the edges of the two provinces are very similar, making it difficult to outline the line between them. In addition, the orosirian magmatism of intracontinental character is a hallmark of both Tapajós and Iriri-Xingu domains. Petrographically, this magmatism is essentially marked by undeformed granitoids and floods of volcanic and volcanoclastic acid rocks. The latter is the majority in the Iriri-Xingu Domain and is represented predominantly by Iriri Group.

In this work, it was shown that Archean source rocks $(2.60 \mathrm{Ga})$ occur within Tapajós Domain, likewise presented by Santos et al. (2000) - 2.53 and 2.60 Ga $\mathrm{T}_{\mathrm{DM}}$ ages - in rocks related to MIS. Semblano et al. (2016) presented paleoproterozoic sources $\left(\mathrm{T}_{\mathrm{DM}}=2.43 \mathrm{Ga}\right)$ to the rocks belonging to I-type Undifferentiated granitoids (Vasquez et al. 2008b) in Iriri-Xingu Domain. These ages, found both in Tapajós and Iriri-Xingu domains, expose the lack of detailed studies (particularly in the transition field between them) and firmer criteria for the geochronological subdivision of the Amazonian Craton.

In fact, the rocks belonging to Iriri-Xingu Domain have source ages that are mostly Archean, and the rocks of Tapajós Domain are mostly paleoproterozoic. However, the $\varepsilon_{\mathrm{Nd}}$ parameter identified in rocks of these domains shows that the contribution of Archean crust in the Iriri-Xingu rocks was more significant than in Tapajós rocks. Orosirian magmatism acted indiscriminately in both domains, released magmas from the mantle which passed by unproportional interaction with Archean magmas of anatetic origin. This episode was responsible for the irregular geochronological pattern observed in the rocks of the edges of these domains. Arndt \& Goldstein (1987) showed that in order to date a crustal formation event by $\mathrm{Sm}-\mathrm{Nd}$ ages satisfactorily, all of the sample material must have come from the mantle during a single event. The obtained negative $\varepsilon_{\mathrm{Nd}(\mathrm{t})}$ values showed that the studied rocks cannot have been produced by mafic magma derived directly from the mantle. When material derived from the mantle mix at different stages, $\mathrm{Sm}-\mathrm{Nd}$ ages reveal only the average time between different episodes of mantle melting. Thus, when Sm-Nd model ages do not agree with any particular orogenic event associated with the magmatism, it should be understood as forming during the mean age of different source mixtures. Moreover, it must be considered that this interaction occurs in a heterogeneous way in different proportions within lithosphere. And this heterogeneity precludes the drawing of a clear boundary between provinces with different $\mathrm{Sm}-\mathrm{Nd}$ model ages, thus making it difficult to separate Tapajós Domain from Iriri-Xingu Domain. One must also consider the zircon crystallization ages, showing that tectonic-magmatic events responsible by formation of these rocks acted simultaneously in both areas.

\section{CONCLUSIONS}

According to the data presented herein, it is possible to include Mamoal, Dalpaiz and Serra Alta plutons in the MIS, even without their crystallization age determination. Firstly, this grouping stems from a compatible geochemical signature with A-type granites, as well as comparative study (petrographic and geochemical) with Maloquinha granite and Moraes Almeida Formation from Lamarão et al. (2002). The rocks belonging to these three plutons have $\mathrm{Ba}$, $\mathrm{Sr}$ and Eu negative anomalies, with a similar pattern to the rocks formed by partial melting. Furthermore, other geochemical characteristics show alkalic-calcic to alkalic nature and affinity with post-collisional and within-plate granites. Their negative $\varepsilon_{\mathrm{Nd}(\mathrm{t})}$ isotopic parameter also reinforces this interpretation, that the rocks were generated by crustal anatexis. All these features point out to a scenario of arc maturity or even transition of orogenic for post-orogenic tectonic environment (Bonin 1990; Barbarin 1999).

These plutons are chronologically correlated with orosirian anorogenic magmatism $(-1.88 \mathrm{Ga})$, well documented in several provinces of the Amazonian Craton. In Carajás Province, it is represented by Jamon and Serra dos Carajás suites, in the Iriri-Xingu Domain by Rio Dourado Intrusive Suite, and northward of craton, in Erepecuru-Trombetas and Uatumã-Anauá domains, by Mapuera Intrusive Suite and to MIS, in the Tapajós Domain. Thus, it is concluded that this anorogenic magmatism not only affected the new terranes that were added to the craton, but also older ones stabilized in the Archean as Carajás Province (Dall'Agnol et al. 2000; Lamarão et al. 2002), and had a large extent with their records ranging northern Amazonian Craton. 
Lamarão et al. (2002) presented two hypotheses for generation of Maloquinha granite and Moraes Almeida Formation. In the first case, the formation of these rocks could be related to a subduction event, and in the second one, they would have generated during an intracontinental magmatic period related to extensional event. In this work, the classification proposed by Eby (1992) to explain petrogenesis of A-type granites was used. So, the MIS rocks were classified as A2-type granites, that is, rocks from underplating derived magmas or from continental crust, which underwent a collisional cycle. They were generated in post-collisional environments with bulk contribution provided from the crustal melting. This conclusion is supported by what was recognized by Pearce (1996) and Foster et al. (1997), who showed that crustal thickening promotes interaction between magmas derived from the mantle and crust that will progressively be stored in the root of the orogen. After complete crustal thickening, in post-orogenic environments, the crust becomes unstable and tends to isostatically relax and extend itself by gravitational collapse once removed compressive stress. Thus, post-collisional environments are easily invaded by trapped magma in the orogen root. Although without crystallization age determinations, it was possible to conclude that the MIS rocks represent a post-orogenic magmatism resulting from Tropas Orogeny that included the Tropas, Parauari, Ingarana, Jutaí, Younger São Jorge and Jardim do Ouro, among other chronocorrelated units in Tapajós Domain.

Proposals of a boundary between Tapajós and IririXingu domains, which basically use $\mathrm{Sm}-\mathrm{Nd}$ model ages as the distinguishing parameter, are unsuitable and difficult to limited mapping. Even if all plutons in the transition between these two domains were mapped, their $\mathrm{Sm}-\mathrm{Nd}$ model ages are not uniform. It is possible to find archean and paleoproterozoic ages in a same pluton, as shown to Mamoal granite in this work. Due to few isotopic studies in Tapajós-Parima Province and mostly in the Central Amazonian Province, it is expected that more contradictory ages to geochronological subdivision models of these two provinces have been found. For exemple, the archean model age in Tapajós Domain, presented in this paper and in Santos et al. (2000), and the paleoproterozoic model age found by Semblano et al. (2016) in Iriri-Xingu Domain. Sm-Nd model ages must be adopted together with others important geological and geochronological information.

\section{ACKNOWLEDGMENTS}

We acknowledge Conselho Nacional de Desenvolvimento Científico e Tecnológico (CNPq) for the fellowship granted to the first author of this work (Grant 132174/2013-8), and the Geology and Geochemistry Post-Graduation Program of the UFPA by the infrastructure provided. The authors also acknowledge CPRM - Brazilian Geological Survey, for the samples and essential geological data provided to carry out this work. The Isotope Geology Laboratory of UFPA (Pará-Iso) and its staff, by support provided in the isotopic analyses, and the National Institute of Science and Geoscience Technology of Amazon (GEOCIAM Institute) are also acknowledged.

\section{REFERENCES}

Almeida C.A.S., Collyer T.A., Pereira J.A.L., Seabra A.S., Furtado A.M.M., Soubes L.F. 1977. Relatório final de reconhecimento (1). Projeto Santarém-Cachimbo. Pesquisa Mineral. Polo Amazônia/Polo Tapajós. Convênio SUDAM/IDESP.

Almeida F.F.M., Hasui Y., Brito Neves B.B., Fuck R.A. 1981. Brazilian structural provinces: an introduction. Earth-Science Reviews, 17:1-29.

Anderson J.L. 1983. Proterozoic anorogenic granite plutonism of North America. In: Medaris L.G., Byers C.W., Mickelson D.M., Shanks W.C. (Eds.). Proterozoic geology. Geological Society of America, 161:133-154.

Andrade A.F., Santiago A.F., Melo C.F., Bizinella G.A., Moreira H.L., Santos J.O.S., Oliveira J.R., Moura P.A., Lopes R.C., Rosa Filho S.F., Neves S.A.V. 1978. Projeto Tapajós / Sucunduri: Relatório de Integração Geológica. Manaus: DNPM/CPRM, 3 v.

Arndt N.T., Goldstein S.L. 1987. Use and abuse of crust-formation ages. Geology, 15:893-895.

Barbarin B. 1996. Genesis of the two main types of peraluminous granitoids. Geology, 24:295-298.

Barbarin B. 1999. A review of the relationships between granitoid types, their origins and their geodynamic enviroments. Lithos, 46:605-626.
Barros M.A.S., Padilha R.A., Rubert R.R., Pimentel M.M., Chemale Jr. F. 2006. Iriri volcanism and Rio Dourado Granite: A-Type Paleoproterozoic Magmatism in northeastern Mato Grosso Brazil. In: Symposium on magmatism, crustal evolution, and metallogenesis of the Amazonian Craton/workshop on A-Type granites and related rocks through time (IGCP 510), 2006, Belém. Abstract volume and Field Trips Guide... Belém: PRONEX-UFPA/ SBG-NO, p.39-39.

Barros M.A.S., Pimentel M.M., Silva F.R., Dantas E.L. 2011. A Suíte Intrusiva Rio Dourado - um granito tipo A de 1,88 Ga sudeste do Cráton Amazônico - Mato Grosso - Brasil. Geologia USP, Série Científica, 11(1):75-93. doi: http://dx.doi.org/10.5327/ Z1519-874X2011000100005.

Bonin B. 1990. From orogenic to anorogenic settings: evolution of granitoid suites after a major orogenesis. Geological Journal, 25:261-270.

Brito M.F.L. 2000. Granito Pepita. In: Almeida M.E.S. et al. (Org.). Geologia e recursos minerais da Folha Vila Mamãe Anã (folha SB.21V-D): Estados do Amazonas e Pará. Escala 1:250.000. Brasília: CPRM, 2000. 1 CD-ROM. Projeto Especial Província Mineral do Tapajós (Promin Tapajós). 
Brito M.F.L., Almeida M.E., Macambira M.J.B. 1999. ${ }^{207} \mathrm{~Pb} /{ }^{206} \mathrm{~Pb}$ age of calk-alkaline Rapakivi granite in Tapajós Gold Province, Amazon Cráton - Brazil. In: South-American symposium on isotope geology, 2., Córdoba, Argentina. 1999. Extended Abstracts... Córdoba, Argentina: 1999. p.40-43.

Brown G.C., Thorpe R.S., Webb P.C. 1984. The geochemical characteristics of granitoids in contrasting arcs and comments on magma sources. Journal of the Geological Society, 141:413-426. doi: 10.1144/gsjgs.141.3.0413.

Chappell B.W., White A.J.R. 1992. I- and S-type granites in the Lachlan Fold Belt. Transactions of the Royal Society of Edinburgh: Earth Sciences, 83:1-26. doi: https://doi.org/10.1017/ S0263593300007720.

Collins W.J., Beams S.D., White A.J.R., Chappell B.W. 1982. Nature and origin of A-type granites with particular reference to southeastern Australia. Contributions to Mineralogy and Petrology, 80:189-200.

Cordani U.G., Tassinari C.G.C., Teixeira W., Basei M.A.S., Kawashita K. 1979. Evolução tectônica da Amazônia com base nos dados geocronológicos. In: Congresso Geológico Chileno, 2., 1979, Arica, Chile. Actas... Arica, Chile: 1979. v.4, p.137-148.

Costi H.T., Dall'Agnol R., Moura C.A.V. 2000. Geology and Pb$\mathrm{Pb}$ Geochronology of Paleoproterozoic Volcanic and Granitic Rocks of Pitinga Province, Amazonian Craton, Northern Brazil. International Geology Review, 42(9):832-849. doi: http://dx.doi. org/10.1080/00206810009465114.

Dall'Agnol R., Lafon J.M., Fraga L.M., Scandolara J.E., Barros C.E.M. 2000. The Precambrian Evolution of the Amazonian Craton. In: International Geological Congress, 31., Geological Survey of Brazil, Rio de Janeiro, Brazil [CD-ROM].

Dall'Agnol R., Rämö O.T., Magalhães M.S., Macambira M.J.B. 1999a. Petrology of the anorogenic, oxidised Jamon and Musa granites, Amazonian Craton: implications for the genesis of Proterozoic A-type granites. Lithos, 46(3):431-462. doi: 10.1016/S0024-4937(98)00077-2.

Dall'Agnol R., Silva C.M.G., Scheller T. 1999b. Fayalite-hedenbergite rhyolites of the Iriri Formation, Tapajós Gold Province, Amazonian Craton: implications for the Uatumã volcanism. In: Simpósio sobre vulcanismo e ambientes associados, 1., Gramado-RS. Boletim de resumos..., Gramado, 1999. p.31.

DePaolo D.J. 1981. A neodymium and strontium isotopic study of the Mesozoic calc-alkaline granitic batholiths of the Sierra Nevada and Peninsular Ranges, California. Journal of Geophysical Research: Solid Earth, 86:10470-10488. doi: 10.1029/JB086iB11p10470.

DePaolo D.J., Wasserburger G.J. 1976. Nd isotopic variations and petrogenetic models. Geophysical Research Letters, 3(5):249-252. doi: 10.1029/GL003i005p00249.

Eby G.N. 1992. Chemical subdivision of the A-type granitoids: petrogenetic and tectonic implications. Geology, 20(7): 641-644. doi: 10.1130/0091-7613(1992)020

Evensen N.M., Hamilton P.J., O’Nions R.K. 1978. Rare-earth abundances in chondritic meteorites. Geochimica et Cosmochimica Acta, 42:1199-1212.

Fernandes C.M.D., Juliani C., Monteiro L.V.S., Lagler B., Misas C.M.E. 2011. High-K calc-alkaline to A-type fissure-controlled volcanoplutonism of the São Félix do Xingu region, Amazonian craton, Brazil: Exclusively crustal sources or only mixed Nd model ages? Journal of South American Earth Sciences, 32(4):351-368. doi: http:// dx.doi.org/10.1016/j.jsames.2011.03.004.

Föster H.J., Tischendorf G., Trumbull R.B. 1997. An evaluation of the $\mathrm{Rb}$ vs. $(\mathrm{Y}+\mathrm{Nb})$ discrimination diagram to infer tectonic setting of silicic igneous rocks. Lithos, 40(2-4):261-293. doi: 10.1016/ S0024-4937(97)00032-7.
Frost B.R., Barnes C.G., Collins W.J., Arculus R.J., Ellis D.J., Frost C.D. 2001. A geochemical classification for granitic rocks. Journal of Petrology, 42(11):2033-2048. doi: 10.1093/petrology/42.11.2033.

Juliani C., Fernandes C.M.D. 2010. Well-preserved Late Paleoproterozoic volcanic centers in the São Félix do Xingu region, Amazonian Craton, Brazil. Journal of Volcanology and Geothermal Research, 191(3-4):167179. doi: http://dx.doi.org/10.1016/j.jvolgeores.2010.01.016.

Juliani C., Rye R.O., Nunes C.M.D., Snee L.W., Corrêa Silva R.H., Monteiro L.V.S., Bettencourt J.S., Neumann R., Neto A.A. 2005. Paleoproterozoic high-sulfidation mineralization in the Tapajós gold province, Amazonian Craton, Brazil: geology, mineralogy, alunite argon age, and stable-isotope constraints. Chemical Geology, 215:95-125.

Klein E.L., Vasquez M.L. (Orgs.). Geologia e recursos minerais da Folha Vila Riozinho - SB.21-Z-A: Estado do Pará. Escala 1:250.000. Brasília: CPRM, 2000. 1 CD-ROM. Programa Levantamentos Geológicos Básicos do Brasil (PLGB). Projeto Especial Província Mineral do Tapajós (Promin Tapajós).

Lamarão C.N. 2001. Geologia, geoquímica e geocronologia do magmatismo paleoproterozóico da região de Vila Riozinho, Província Aurífera doTapajós, Cráton Amazônico. Tese (Doutorado em Geologia e Geoquímica) - Universidade Federal do Pará, Coordenação de Aperfeiçoamento de Pessoal de Nível Superior.

Lamarão C.N., Dall'Agnol R., Lafon J.M., Lima E.F. 2002. Geology, geochemistry, and $\mathrm{Pb}-\mathrm{Pb}$ zircon geochronology of the Paleoproterozoic magmatism of Vila Riozinho, Tapajós Gold Province, Amazonian craton, Brazil. Precambrian Research, 119(1-4):189-223. doi: http:// dx.doi.org/10.1016/S0301-9268(02)00123-7.

Lamarão C.N., Dall'Agnol R., Pimentel M.M. 2005. Nd isotopic composition of Paleoproterozoic volcanic and granitoid rocks of Vila Riozinho: implications for the crustal evolution of the Tapajós gold province, Amazon Craton. Journal of South American Earth Sciences, 18(3-4):277-292. doi: http://dx.doi.org/10.1016/j.jsames.2004.11.005.

Lameyre J., Bowden P. 1982. Plutonic rock types series: discrimination of various granitoid series and related rocks. Journal of Volcanology Geothermal Research, 14(1-2):169-186. doi: 10.1016/0377-0273(82)90047-6.

Loiselle. M.C., Wones D.R. 1979. Characteristics and origin of anorogenic granites. Geological Society of America Abstracts with Programs, 11(7):468.

Moura C.A.V., Gorayeb P.S.S., Matsuda N.S. 1999. Geocronologia Pb$\mathrm{Pb}$ em zircão do riolito Vila Raiol, Formação Iriri - sudoeste do Pará. In: Simpósio de Geologia da Amazônia, 6., 1999, Manaus. Resumos expandidos... Manaus: SBG, 1999. p.475-477.

Oliveira E.C., Lafon J.M., Gioia S.M.C.L., Pimentel M.M. 2008. Datação Sm-Nd em rocha total e granada do metamorfismo granulítico da região de Tartarugal Grande, Amapá Central. Revista Brasileira de Geociências, 38(1):114-127.

Patiño Douce A.E. 1997. Generation of metaluminous A-type granites by low pressure melting of calc-alkaline granitoids. Geology, 25(8):743-746. doi: 10.1130/0091-7613(1997)025.

Pearce J. 1996. Sources and settings of granitic rocks. Episodes, 19(4):120-125

Pessoa M.R., Santiago A.F., Andrade A.F., Santos J.O.S., Prazeres W.V. 1977. Projeto Jamanxim. Brasil: Ministério das Minas e Energia. Convênio DNPM/CPRM, Relatório Inédito. v.8.

Pitcher W.S. 1983. Granite type and tectonic environment. In: Hsu K.J. (Ed.). Mountain Building Processes. London, Academic Press. p. 19-40.

Ragland P.C. 1989. Basic analytical petrology. 2. ed. New York, Oxford University Press, $384 \mathrm{p}$.

Rollison H.R. 1993. Using geochemical data: evaluation, presentation, interpretation. New York, Longman, $352 \mathrm{p}$. 
Santos D.B., Fernandes P.E.C.A., Dreher A.M., Cunha F.M.B., Basei M.A.S., Teixeira W. 1975. Geologia da Folha SB.21, Tapajós. In: Brasil: Ministério das Minas e Energia. Projeto RADAMBRASIL. Rio de Janeiro, DNPM. (Levantamentos de Recursos Minerais, 7).

Santos J.O.S. 2003. Geotectônica dos escudos das Guianas e BrasilCentral. In: Bizzi, L.A., Schobbenhaus, C., Vidotti R.M., Gonçalves J.H. (Eds.). Geologia, tectônica e recursos minerais do Brasil. CPRM, Brasília. p. $169-226$

Santos J.O.S., Groves D.I., Hartmann L.A., Moura M.A., Mcnaughton N.J. 2001. Gold deposits of the Tapajós and Alta Floresta Domains, Tapajós-Parima orogenic belt, Amazon Craton, Brazil. Mineralium Deposita, 36(3):278-299. doi: doi:10.1007/s001260100172.

Santos J.O.S., Hartmann L.A., Gaudette H.E., Groves D.I., Mcnaughton N.J., Flecher I.R. 2000. A new understanding of the provinces of the Amazon Craton based on integration of field mapping and $\mathrm{U}-\mathrm{Pb}$ and Sm-Nd Geochronology. Gondwana Research, 3(4):453-488.

Santos J.O.S., Van Breemen O.B., Groves D.I., Hartmann L.A., Almeida M.E., Mcnaughton N.J., Fletcher I.R. 2004. Timing and evolution of multiple paleoproterozoic magmatic arcs in the Tapajós Domain, Amazon Craton: constraints from SHRIMP and TIMS zircon, baddeleyite and titanite U-Pb geochronology. Precambrian Research, 131:73-109. doi: doi:10.1016/j.precamres.2004.01.002.

Semblano F.R.D., Pereira N.C.S, Vasquez M.L, Macambira M.J.B. 2016. Novos dados geológicos e isotópicos para o Domínio Iriri-Xingu, Província Amazônia Central: implicações para a idade do Grupo Iriri. Geologia USP, Série Científica, 16(3):19-38. doi: http://dx.doi. org/10.11606/issn.2316-9095.v16i3p19-38.

Shand S.J. 1951. Eruptive rocks: their genesis, composition, classification and their relation to ore-deposit with a chapter on meteorites. 4. ed. New York, Wiley, 488p.

Streckeisen A.L. 1976. To each plutonic rock its proper name. EarthScience Reviews, 12(1):1-33. doi: 10.1016/0012-8252(76)90052-0.

Tassinari C.C.G. 1996. O mapa geocronológico do Cráton Amazônico no Brasil: revisão dos dados isotópicos. São Paulo, 139 p. Tese Livre-Docência, Instituto de Geociências, Universidade de São Paulo, São Paulo.

Tassinari C.C.G., Macambira M.J.B. 1999. Geochronological provinces of the Amazonian Craton. Episodes, 22(3):174-182.

Tassinari C.C.G., Macambira M.J.B. 2004. A evolução tectônica do Cráton Amazônico. In: Mantesso-Neto V., Bartorelli A., Carneiro C.D.R., Brito Neves B.B. (Eds.). Geologia do continente Sul-americano: evolução da obra de Fernando Flávio Marques de Almeida. São Paulo, Beca. p. 471-485.
Teixeira W., Tassinari C.C., Cordani U.G., Kawashita K. 1989. A review of the geochronology of the Amazonian Craton: tectonic implications. Precambrian Research, 42(3-4):213-27. doi: 10.1016/0301-9268(89)90012-0.

Vasquez M.L., Klein E.L., Quadros M.L.E.S., Bahia R.B.C., Santos A., Ricci P.S.F., Sachett C.R., Silva C.M.G., Macambira M.J.B. 1999. Magmatismo Uatumã na Província Tapajós - novos dados geocronológicos. In: Simpósio de Geologia da Amazônia, 6., Manaus. Resumos expandidos. Manaus: SBG-Núcleo Norte. p.471-474.

Vasquez M.L., Klein E.L., Ricci P.S.F. 2002. Granitóides pós-colisionais da porção leste da Província Tapajós. In: Klein E.L., Vasquez M.L. Rosa-Costa L.T. (Eds.). Contribuições à Geologia da Amazônia. SBGNúcleo Norte, Belém. 3:67-84

Vasquez M.L., Rosa-Costa L.T., Silva C.M.G., Klein E.L. 2008a. Compartimentação Tectônica. In: Vasquez M.L., Rosa-Costa. L.T. (Orgs.). Geologia e recursos minerais do estado do Pará: Sistema de Informações Geográficas - SIG: texto explicativo dos mapas geológico e tectônico e de recursos minerais do estado do Pará Escala 1:1.000.000. Belém, CPRM.

Vasquez M.L., Rosa-Costa L.T., Silva C.M.G., Ricci P.S.F., Barbosa J.P.O., Klein E.V., Lopes E.C.S., Macambira E.M.B., Chaves C.L., Carvalho J.M.A., Oliveira J.G.F., Anjos G.C., Silva H. R. 2008b. Unidades litoestratigráficas. In: Vasquez M.L., Rosa-Costa. L.T. (Orgs.). Geologia e recursos minerais do estado do Pará: Sistema de Informações Geográficas - SIG: texto explicativo dos mapas geológico e tectônico e de recursos minerais do estado do Pará. Escala 1:1.000.000. Belém, CPRM.

Vasquez M.L., Chaves C.L., Moura E.M., Oliveira J.H.M. 2014a. Carta Geológica da Folha SB.21-Z-A-III - Jardim do Ouro. Escala 1:100.000. CPRM.

Vasquez M.L., Chaves C.L., Moura E.M., Oliveira J.H.M. 2014b. Carta Geológica da Folha SB.21-Z-A-II - São Domingos. Escala 1:100.000. CPRM.

Whalen J.B., Currie K.L., Chappell B.W. 1987. A-type granites: geochemical characteristics, discrimination and petrogenesis. Contributions to Mineralogy and Petrology. 95(4):407-419. doi 10.1007/BF00402202

Wood D.A. 1979. A variably veined suboceanic upper mantle genetic significance for mid-ocean ridge basalts from geochemical evidence. Geology, 7(10):499-503. doi: 10.1130/0091-7613(1979)7.

Available at www.sbgeo.org.br 